San Jose State University

SJSU ScholarWorks

Master's Theses

Master's Theses and Graduate Research

Spring 2018

\title{
Structure and Emplacement of the Eocene Golden Horn Batholith, North Cascades, Washington
}

Christopher Scudder

San Jose State University

Follow this and additional works at: https://scholarworks.sjsu.edu/etd_theses

\section{Recommended Citation}

Scudder, Christopher, "Structure and Emplacement of the Eocene Golden Horn Batholith, North Cascades, Washington" (2018). Master's Theses. 4919.

DOI: https://doi.org/10.31979/etd.p6p4-am45

https://scholarworks.sjsu.edu/etd_theses/4919

This Thesis is brought to you for free and open access by the Master's Theses and Graduate Research at SJSU ScholarWorks. It has been accepted for inclusion in Master's Theses by an authorized administrator of SJSU ScholarWorks. For more information, please contact scholarworks@sjsu.edu. 


\title{
STRUCTURE AND EMPLACEMENT OF THE EOCENE GOLDEN HORN BATHOLITH, NORTH CASCADES, WASHINGTON
}

\author{
A Thesis \\ Presented to \\ The Faculty of the Department of Geology \\ San José State University \\ In Partial Fulfillment \\ of the Requirement for the Degree \\ Master of Science
}

by

Christopher A. Scudder

May 2018 
(C) 2018

Christopher A. Scudder

ALL RIGHTS RESERVED 
The Designated Thesis Committee Approves the Thesis Titled

STRUCTURE AND EMPLACEMENT OF THE EOCENE GOLDEN HORN BATHOLITH, NORTH CASCADES, WASHINGTON

by

Christopher A. Scudder

APPROVED FOR THE DEPARTMENT OF GEOLOGY

SAN JOSÉ STATE UNIVERSITY

May 2018
Dr. Robert Miller
Department of Geology
Dr. Ellen Metzger
Department of Geology
Dr. Jonathan Miller
Department of Geology 


\section{ABSTRACT \\ STRUCTURE AND EMPLACEMENT OF THE EOCENE GOLDEN HORN BATHOLITH, NORTH CASCADES, WASHINGTON}

By Christopher A. Scudder

The 48 Ma Golden Horn batholith is a $\sim 310 \mathrm{~km}^{2}$, shallow intrusion constructed of sub-horizontal sheets in the crystalline core of the North Cascades of Washington. It is the only large body of granite in an orogen dominated by 96-45 Ma tonalite, and probably intruded during ridge subduction. The oldest and structurally highest unit of the batholith is diorite, followed by alkaline granite, one feldspar-biotite granite, two feldspar-biotite granite, and finally granodiorite, the youngest and structurally lowest unit. The batholith displays a weak NE-striking foliation restricted to the center of the intrusion and a stronger NW-striking foliation formed throughout the batholith with an associated weak, NW-trending and shallowly plunging lineation. Foliation is coupled across the northwestern and parts of the southern contact, and likely records a NE-SW shortening component in an overall transtensional regime. Most Golden Horn dikes intruding host rock are felsic, but there are some mafic dikes. These steeply dipping dikes tend to form swarms and strike NE and E-W. The NE-striking dikes reflect regional NW-SE extension. Parts of the southern contact are marked by xenolith-rich zones, which are 100 m wide and several $\mathrm{km}$ long, and lend evidence to stoping as an emplacement mechanism. The diking, stoped blocks, and lack of a ductile aureole are compatible with shallow batholith emplacement models. 


\section{ACKNOWLEDGMENTS}

This thesis is the culmination of several people's hard work and kind charity. My wife Susan Marie Scudder was my backbone, assisting me in the mountains of Northern Washington, and for being my inspiration. A special thanks to Jeff Tepper from the University Of Puget Sound for leading me safely there and back again to some very remote locations. My committee members, Jonathan Miller and Ellen Metzger are thanked for helping me to keep an open mind. Finally, I would like to thank my advisor Robert Miller, who has helped to evolve my writing into one of academic integrity and for having faith in me to finish this research project. This work was supported by National Science Foundation grant EAR-1119358 to Robert Miller. 


\section{TABLE OF CONTENTS}

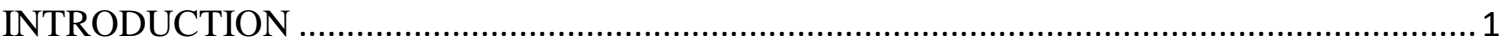

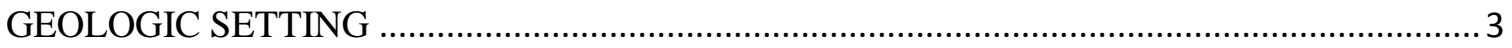

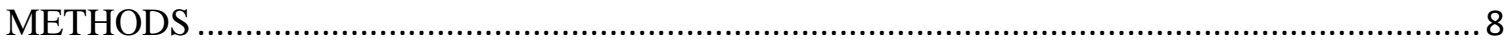

ROCK UNITS

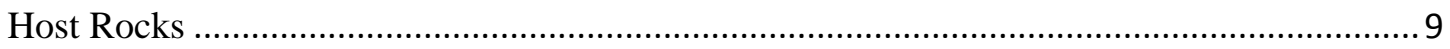

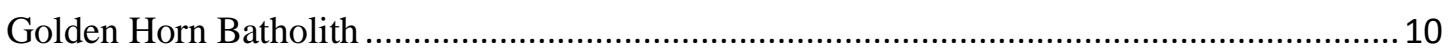

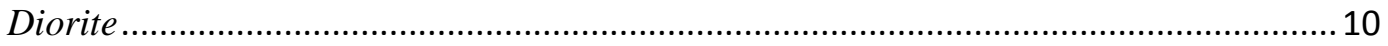

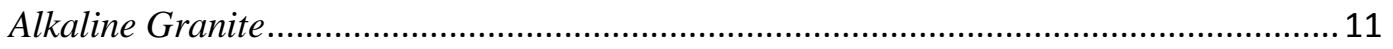

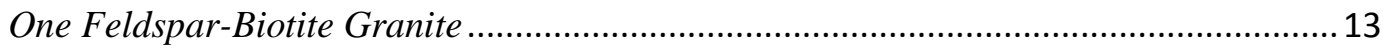

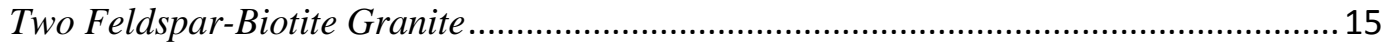

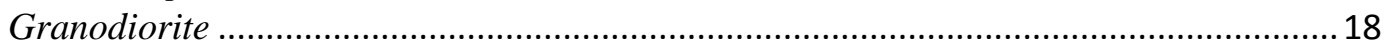

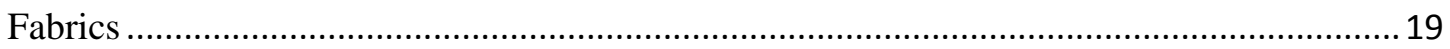

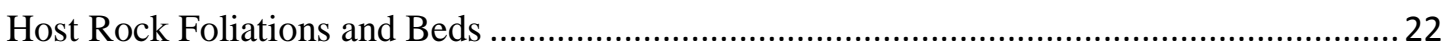

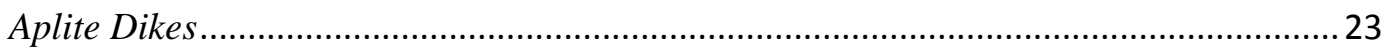

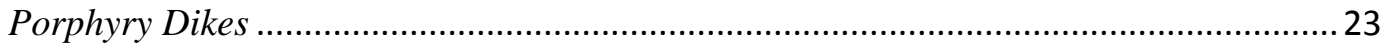

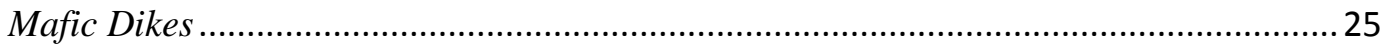

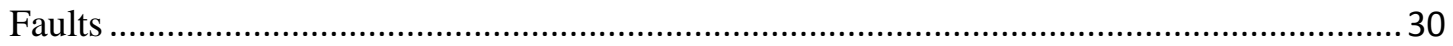

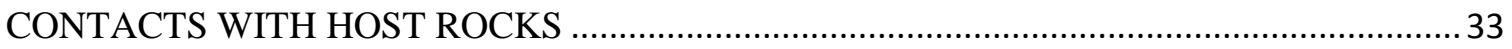

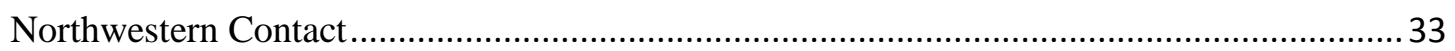

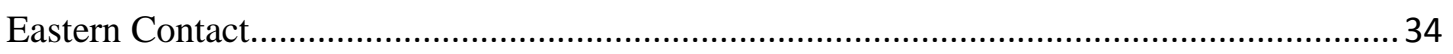

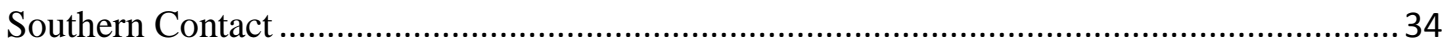

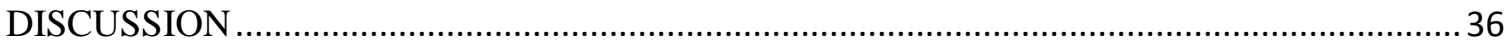

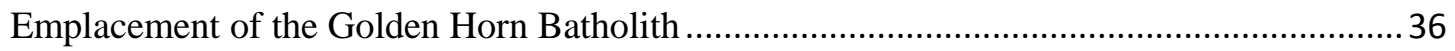

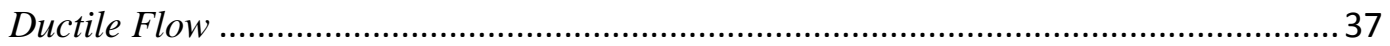

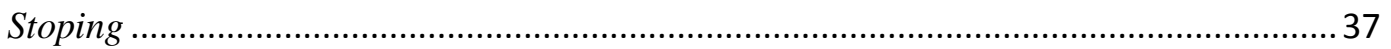

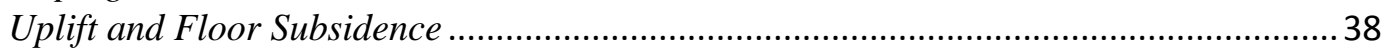

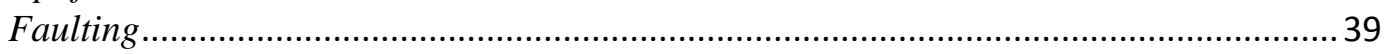

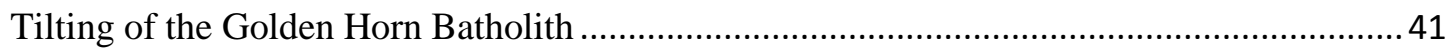

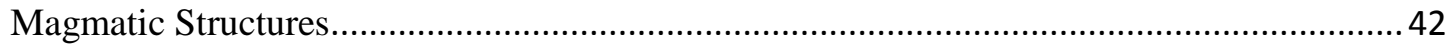

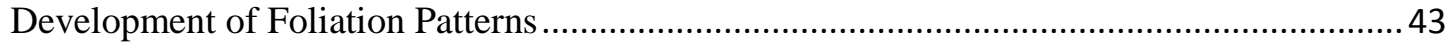

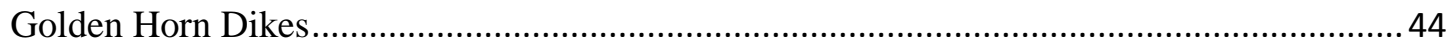

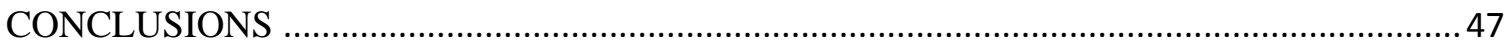

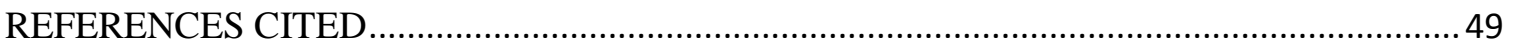




\section{LIST OF FIGURES}

Figure 1. Simplified geologic map of the North Cascades of Washington ....................4

Figure 2. Geologic map of Golden Horn batholith and host rocks ...........................

Figure 3. Thin section in cross polarization of alkaline granite ................................ 12

Figure 4. Alkaline granite containing sodic amphiboles ........................................ 13

Figure 5. Thin section in cross polarization of one feldspar-granite showing biotite, myrmekite, and perthite ..................................................................... 14

Figure 6. Mafic enclave in one feldspar-granite................................................ 16

Figure 7. Thin section in cross polarization of two feldspar-granite showing rapikivi texture and embayed quartz ............................................................. 17

Figure 8. Mafic granodiorite talus near the northwest end of the batholith .................. 19

Figure 9. Poles to magmatic foliations within the Golden Horn batholith.................... 20

Figure 10. Map of the southern half of the Golden Horn batholith showing internal foliation and host rock foliation and bedding ...................................... 21

Figure 11. Stereographic projection of poles to planes of aplite dikes ......................... 24

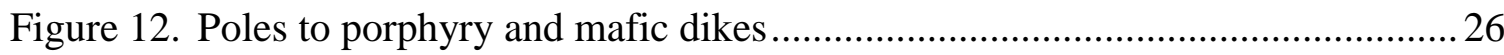

Figure 13. Outcrop of rapikivi porphyry dike ....................................................... 27

Figure 14. Simplified map showing Golden Horn dikes intruding host rock near the southern and southwestern contact of the Golden Horn batholith

Figure 15. Simplified map showing dikes between the Golden Horn batholith and the Monument Peak pluton

Figure 16. Photo facing west of two mafic Golden Horn dikes intruding the Black Peak batholith at Silent Lakes.

Figure 17. Simplified map of faults to the north, east, and south of the Golden Horn batholith 
Figure 18. Xenoliths of metavolcanic rocks of the Midnight Peak Formation near

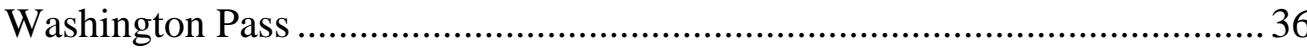

Figure 19. Simplified map of regional dike orientations in the North Cascades ............ 46 


\section{INTRODUCTION}

Plutons are topics of intense scientific research, but despite the vast amount of literature, the construction and emplacement of these intrusive bodies is still controversial. One reason for this is that clear evidence of emplacement is commonly overprinted as the system evolves (e.g., Paterson et al., 1996; 1998; Petford, 2003). In addition, plutons intrude a wide variety of host rocks, different crustal levels, and in different tectonic settings, and range greatly in size and shape. These factors lead to several major questions. For example, what are the sizes and numbers of intrusive increments, and how large are the resultant magma chambers? What emplacement mechanisms accommodate large plutons? How do plutons interact with and potentially record regional strain?

Mechanisms for magma ascent include diapirism and diking. Large magma diapirs rise through the crust by partially melting the surrounding host rock creating a ductile flow layer (e.g., Marsh, 1982; Weinberg, 1994; Petford, 1996) or ascend through rocks exhibiting visco-elastic behavior (Miller and Paterson, 1999). Given the rate of heat loss through relatively cool host rock, and without recharge of heat from younger magma, it is unlikely that diapirs can reach the upper crust before thermal arrest unless rates of ascent are in the 10- to-100 m/yr range (Weinberg, 1994). A more widely accepted mechanism for magma ascent is diking (e.g., Clemens and Mawer, 1992; Petford et al., 2000). This model states that magma ascends rapidly, commonly along faults and fractures, building plutons from numerous sheets through recharge of magma (Weinberg, 1999; Petford et al., 2003). 
Pluton emplacement fundamentally deals with making space or transferring material in the crust, and the only ways to make space are by either displacing the Moho below the intrusion or upwardly displacing the Earth's surface. Roof uplift and shouldering aside of the host rock are two material transfer processes that accommodate emplacement above and around mid- to shallow-crustal plutons (e.g., Corry, 1988; Paterson et al., 1996; Benn et al., 1999). In roof uplift, host rocks are domed, detached, or extended by faults. Vertical and horizontal deflection of pre-emplacement markers such as beds, faults, foliations, and dikes is also evidence of roof uplift or shouldering (e.g., McNulty et al., 1996).

Other material transfer processes do not increase the volume of the crust. One commonly cited process is ductile flow of wall rocks around a pluton (e.g., Buddington, 1959; Paterson and Fowler, 1993), which results in a ductile structural aureole. Stoping of host rock is another material transfer process whereby blocks are detached from the sidewalls and/or roof of a magma chamber and sink and/or melt, allowing the pluton to expand laterally and vertically. Evidence of stoping includes xenoliths of host rock within the pluton, and sharp, stepped contacts (e.g., Marsh, 1982; Clarke et al., 1998). Lateral extension by dilational faulting is an additional material transfer process (e.g., Hutton, 1988; 1992), and faults can also provide anisotropic pathways for ascending magma.

Foliation and lineation may provide important information on the mechanisms of pluton construction and emplacement, and on regional strain (Paterson et al., 1998). In magmatic systems that are decoupled from their host rocks, magmatic foliation and 
lineation patterns may result from the final increments of strain induced by internal processes during emplacement, but increased coupling of foliation between magma and host rock may reflect regional deformation (Buddington, 1959; Paterson et al., 1998).

The crystalline core of the North Cascades of Washington contains numerous plutons emplaced at varying depths (Miller et al., 2009a), making it an ideal place to compare how emplacement mechanisms may change with depth, types of host rocks, and composition. This thesis focuses on foliation patterns, dikes, and emplacement of the shallow Golden Horn batholith, which was emplaced into a major fault zone and into several different host rock units.

\section{GEOLOGIC SETTING}

The crystalline core of the Northern Cascades forms a 1500-km-long plutonic and metamorphic belt, and is part of the Coast Plutonic Complex, which represents a Mesozoic and Paleogene magmatic arc (Fig. 1) (e.g., Misch, 1966; Tabor et al., 1989; Gehrels et al., 2009; Miller et al., 2009a). It has been postulated that during the Eocene ( $50 \mathrm{Ma})$, subduction of an oceanic ridge occurred in the Pacific Northwest (e.g, Thorkelson and Taylor, 1989; Cowan, 2003; Haeussler et al., 2003; Madsen et al., 2006; Eddy et al., 2016b) creating a slab window. Ridge subduction commonly results in anomalous magma compositions (e.g., Johnston and Thorkelson, 1997; Madsen et al., 2006). The Eocene ( $\sim 50-45 \mathrm{Ma})$ magmatism is characterized by granodiorite, granite, and peralkaline rocks in the North Cascades, which contrasts with the dominantly tonalite, $96-60$ Ma arc plutonism (Misch, 1966). 


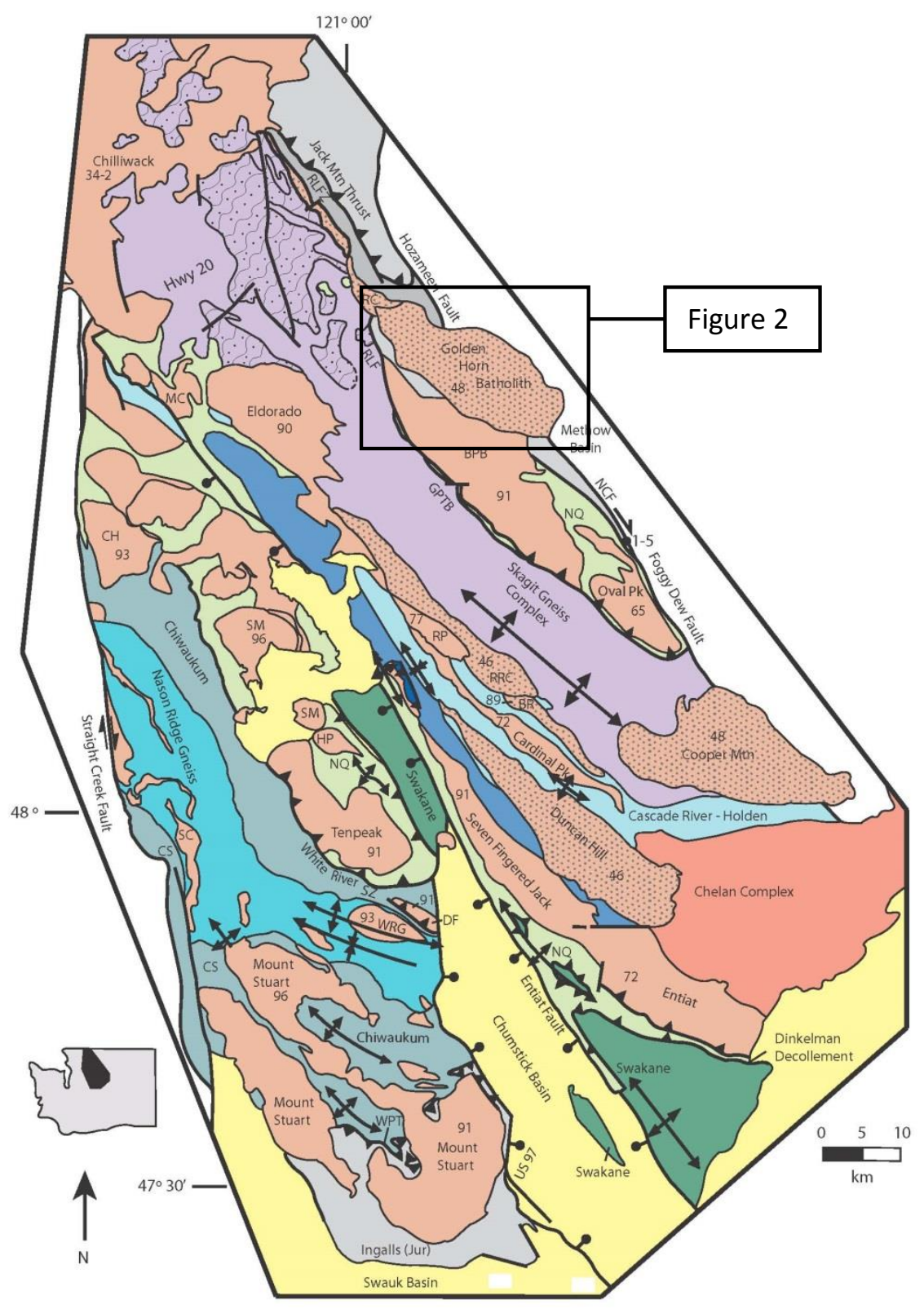

Figure 1. Simplified geologic map of the North Cascades of Washington (modified from Miller et al., 2009b). BPB — Black Peak batholith; BR - Bearcat Ridge Orthogneiss; $\mathrm{CH}$ - Chaval pluton; CS - Chiwaukum Schist; DF - Dirtyface pluton; GPTB - Gabriel Peak tectonic belt; HP — High Pass pluton; MC —-Marble Creek pluton; NCF_-North Creek fault; NQ - Napeequa unit; RRC - Railroad Creek pluton; RLF-Ross Lake fault; RLFZ - Ross Lake fault zone; RP — Riddle Peaks pluton; SC — Sloan Creek plutons; SM-Sulphur Mountain pluton; WPT — Windy Pass thrust; WRG_-Wenatchee Ridge Gneiss. 
The Eocene magmatic episode is thus thought to represent slab window or slab breakoff magmatism (Thorkelson and Taylor, 1989; Cowan, 2003; Haeussler et al., 2003; Madsen et al., 2006; Eddy et al., 2016b).

The Cascades core is bound to the west by the Eocene dextral Straight Creek-Fraser River fault, which separates it from Paleozoic and Mesozoic island arc and oceanic terranes (Misch, 1966). To the east, the Paleogene Ross Lake fault zone separates the core from the Mesozoic Methow basin (Misch, 1966; Miller and Bowring, 1990). The major internal structure of the Cascades core is the high-angle Eocene Entiat fault, which divides the core into the Wenatchee block to the southwest and the Chelan block to the northeast (Tabor et al, 1989).

The Ross Lake fault zone is a 10-km-wide fault system (Misch, 1966; Miller, 1994) that is part of a 500-km-long zone of northwest-striking, high-angle Paleogene faults (Monger et al., 1994; Umhoefer and Miller, 1996). The fault zone records dextral shear, with components of early reverse slip and Eocene ( 50-48 Ma) oblique dextral-normal slip (Miller and Bowring, 1990).

During the Eocene ( $55 \mathrm{Ma})$ there was a shift from regional transpression to transtension in the North Cascades and southern British Columbia (Parrish et al., 1988; Miller and Bowring, 1990). This transition has been interpreted as a response to a change in the motion between the North America and Farallon plates. The Farallon plate subducted below British Columbia, Washington, and Oregon from at least 96-60 Ma (Madsen, 2006), but subduction of an oceanic ridge between the Farallon and Resurrection or Kula plate, which started at $\sim 50 \mathrm{Ma}$, created a slab window beneath the 
North American plate, and thus may explain the change from dominantly tonalite to granodiorite (Misch, 1966; Miller et al., 2009a). All magmatism, ductile deformation, and metamorphism ended by 44 Ma (Engels et al., 1976; Wernicke and Getty, 1997; Miller et al., 2016). This study focuses on the Eocene Golden Horn batholith, which intruded at shallow levels along the eastern margin of the crystalline core of the North Cascades (Fig. 2). The Golden Horn batholith was first described by Misch (1966) in a synthesis of the tectonic evolution of the Northern Cascades. Subsequent studies focused on the geochemical (Stull, 1969), mineralogical (Boggs, 1984), and geochronological (Eddy et al., 2016a) aspects of the batholith. Apart from a brief description in a field guide by Miller et al. (2009b), almost no structural data has been collected from the Golden Horn batholith.

The Golden Horn batholith intruded the Ross Lake fault zone, which separates the Methow basin to the east from the Skagit Gneiss Complex to the west. The Skagit Gneiss Complex is one of the two regions of deep crust exhumed in the Eocene in the North Cascade crystalline core (Misch, 1966; Miller et al., 2016). Along the western contact of the Golden Horn batholith, there are metasandstones and metavolcanic rocks interpreted as parts of the Cretaceous Virginian Ridge and Midnight Peak formations, respectively, of the Methow basin (Misch, 1966; Miller et al., 1994; Haugerud and Tabor, 2009). The Methow basin is a fault-bounded block of Cretaceous and Jurassic sedimentary and lesser volcanic strata, and lies between the crystalline core of the North Cascades and the Okanogan Range batholith (Misch, 1966; Barksdale, 1975). 


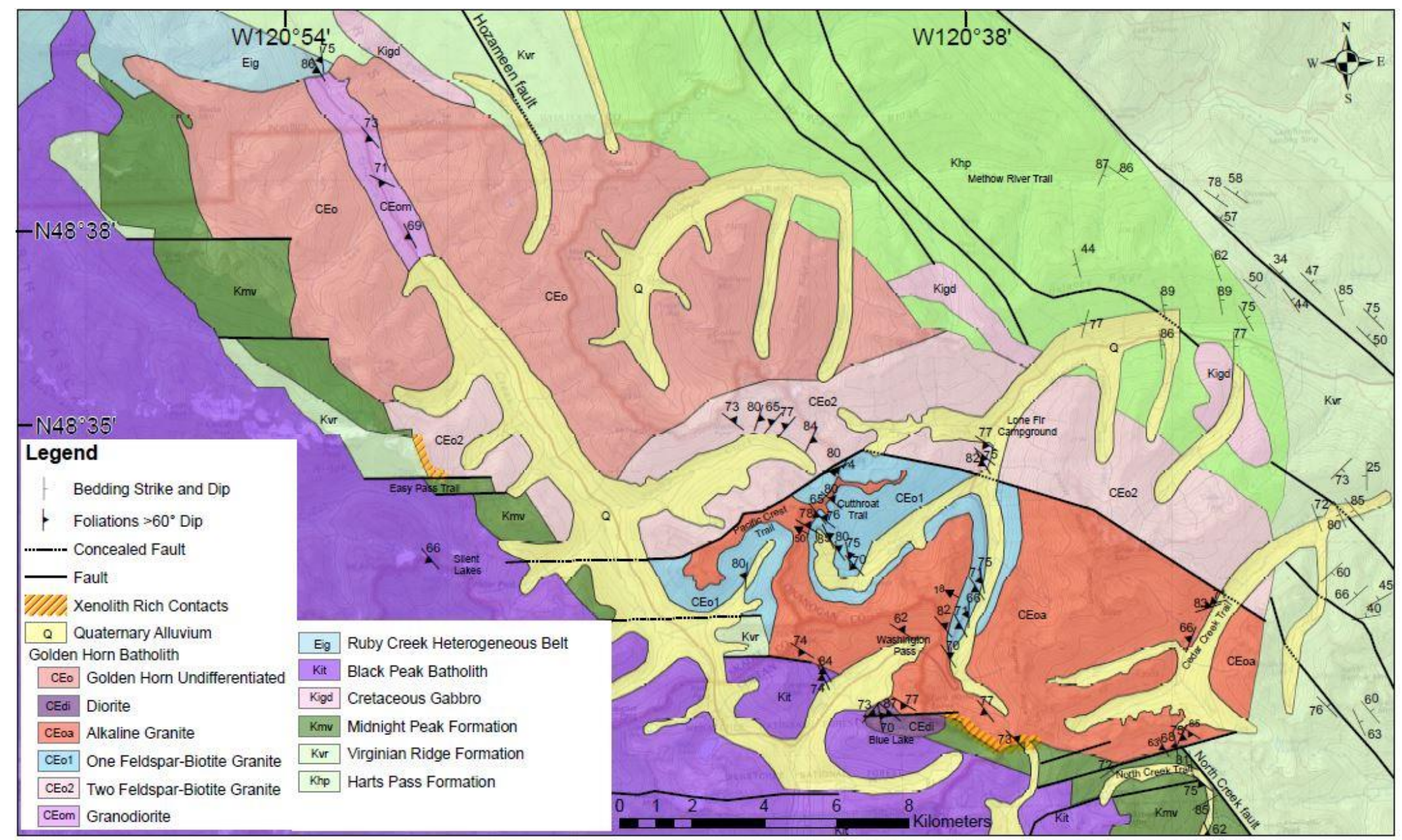

Figure 2. Geologic map of Golden Horn batholith and host rocks. 
The Ross Lake fault zone is also intruded to the northwest of the Golden Horn batholith by the Eocene Ruby Creek heterogeneous plutonic belt, and to the southeast by the Eocene (48 Ma) Cooper Mountain batholith (Misch, 1966) (Fig. 1). The zone deforms the Cretaceous ( 90 Ma) Black Peak batholith to the SW of the Golden Horn batholith (Fig. 1).

The Golden Horn batholith is unique for the North Cascades as parts of it have alkaline composition in an orogen dominated by tonalite (Misch, 1966). Recent U-Pb zircon dating of rocks of the Golden Horn batholith indicates emplacement from $48.468 \pm$ 0.037 Ma to 47.729 $\pm 0.026 \mathrm{Ma}$ (Eddy et. al., 2016a). The emplacement of this voluminous pluton is estimated to have taken only $739 \pm 34$ k.y., and much of it was intruded over only $26 \pm 25$ k.y. at ca. 48.3 Ma (Eddy et. al., 2016a).

The Golden Horn batholith provides an excellent opportunity to study the emplacement and construction mechanisms for shallow and rapidly emplaced intrusions. It also has the potential to offer insight into the regional strain regime at the time of intrusion.

\section{METHODS}

This study concentrates on the construction, emplacement, and structure of the Golden Horn batholith. Field data were collected over six weeks during the summer of 2012. Given the size of the batholith $\left(\sim 310 \mathrm{~km}^{2}\right)$, only select areas were mapped in relative detail. These areas were mapped at 1:10,000 where possible, such as at the Silent Lakes, Blue Lake, Cutthroat Trail, and Washington Pass areas (see Fig. 2 for locations), and at 1:24,000 elsewhere. Foliations and lineations were measured to determine if they 
dominantly record regional or internal magmatic patterns, and to help determine emplacement mechanisms. Other features, including dikes, enclaves, schlieren, internal contacts, and xenoliths, were studied in detail. Contacts and host rock structures were examined to help evaluate emplacement processes. Twenty-one thin sections were analyzed for modal mineralogy, grain orientation, and the degree of solid-state deformation.

\section{ROCK UNITS}

\section{Host Rocks}

The host rock to the north and east of the Golden Horn batholith is the Methow basin. The Golden Horn batholith intrudes the Cretaceous Virginian Ridge, Midnight Peak, and Harts Pass Formations of the basin. Along the Cedar Creek Trail (Fig. 2), shales of the Virginian Ridge Formation were mapped, and along the Methow River Trail (Fig. 2), conglomerates of the Harts Pass Formation were observed. To the west, between the Black Peak batholith and the Golden Horn batholith, there are screens of intermediategrade metaconglomerate and metavolcanic rock of the Virginian Ridge and Midnight Peak Formations, respectively. To the southeast of the Golden Horn batholith and east of the Black Peak batholith, the Virginian Ridge Formation and Midnight Peak Formation are separated from their metamorphosed counterparts by the dextral, northwest-striking North Creek fault (Fig. 1).

To the south and southwest is the Black Peak batholith, a 90 Ma ellipsoidal-shaped intrusion consisting dominantly of tonalite and granodiorite (Adams, 1961; Shea et al., 2016). Diorite, gabbro, and hornblendite are exposed along the eastern margin, and the 
tonalite and granodiorite change from hornblende-bearing in the north and west to hornblende-absent in the south (Adams, 1964; Miller, 1987). The intrusion has been deformed by Paleogene shear zones of the Ross Lake fault zone, and by Cretaceous to Eocene regional deformation (Miller, 1994; Dragovich et al., 1997).

The Ruby Creek heterogeneous plutonic belt extends from the Golden Horn batholith to the northwest (Misch, 1966). This belt is at least in part Eocene (Miller et al., 2016), and includes numerous small ( $<100 \mathrm{~m}$ across) bodies that range from hornblende gabbro to trondhjemite (Miller et al., 1994). It lies within an extensional stepover of the Ross Lake fault zone.

\section{Golden Horn Batholith}

The southern portion of the Golden Horn batholith was mapped in detail for this study, and the following descriptions and subsequent discussion are based mostly on features observed in this part of the batholith. A smaller area next to the northwestern contact of the batholith was also mapped in detail. The Golden Horn batholith consists of five units. The oldest and structurally highest unit is diorite, followed by alkaline granite, one feldspar-biotite granite, two feldspar-biotite granite, and finally granodiorite, the youngest and structurally lowest unit (Eddy et al., 2016a).

\section{Diorite}

The $48.468 \pm 0.030 \mathrm{Ma}$ diorite is located in the southern margin of the batholith where it is in contact with the Black Peak batholith and metasedimentary rocks of the Virginian Ridge Formation (Fig. 2). The contact between the diorite and its host rocks is 
steep and sharp. The unit is comprised of coarse-grained plagioclase, hornblende, and biotite.

\section{Alkaline Granite}

The $48.35 \pm 0.015 \mathrm{Ma}$ (Eddy et al., 2016a) alkaline granite is a white, mediumgrained, structureless mass that is homogeneous across the map area. It forms an E-Wtrending band in map view in the southern part of the batholith that is $\sim 8 \mathrm{~km}$ wide and 20 $\mathrm{km}$ long (Fig. 2). The alkaline granite is in contact with the two feldspar-biotite granite to the north and northeast and the one feldspar-biotite granite to the northwest. This latter contact is shallowly dipping $\left(<20^{\circ}\right)$ and was only observed for tens of meters north of Washington Pass; the rest of the mapped contact was measured indirectly.

The alkaline granite is dominated by anhedral quartz and perthite, which exhibits Carlsbad twinning (Fig. 3), and minor amounts of sodic amphibole. It lacks biotite, in contrast to the one feldspar-biotite granite. The scarcity of mafic minerals in this granite makes it difficult to find lineation and foliation.

This granite contains widespread miarolitic cavities, ranging from the millimeter to meter scale. Quartz and perthite are euhedral in the miarolitic cavities. Over 60 minerals have been found in the alkaline granite (Stull, 1969), many of them in the miarolitic cavities (Boggs, 1984). Along the southern contact near Cedar Pass (Fig. 2), small accumulations of mafic minerals were observed with sodic amphibole and myrmekite (Fig. 4). 


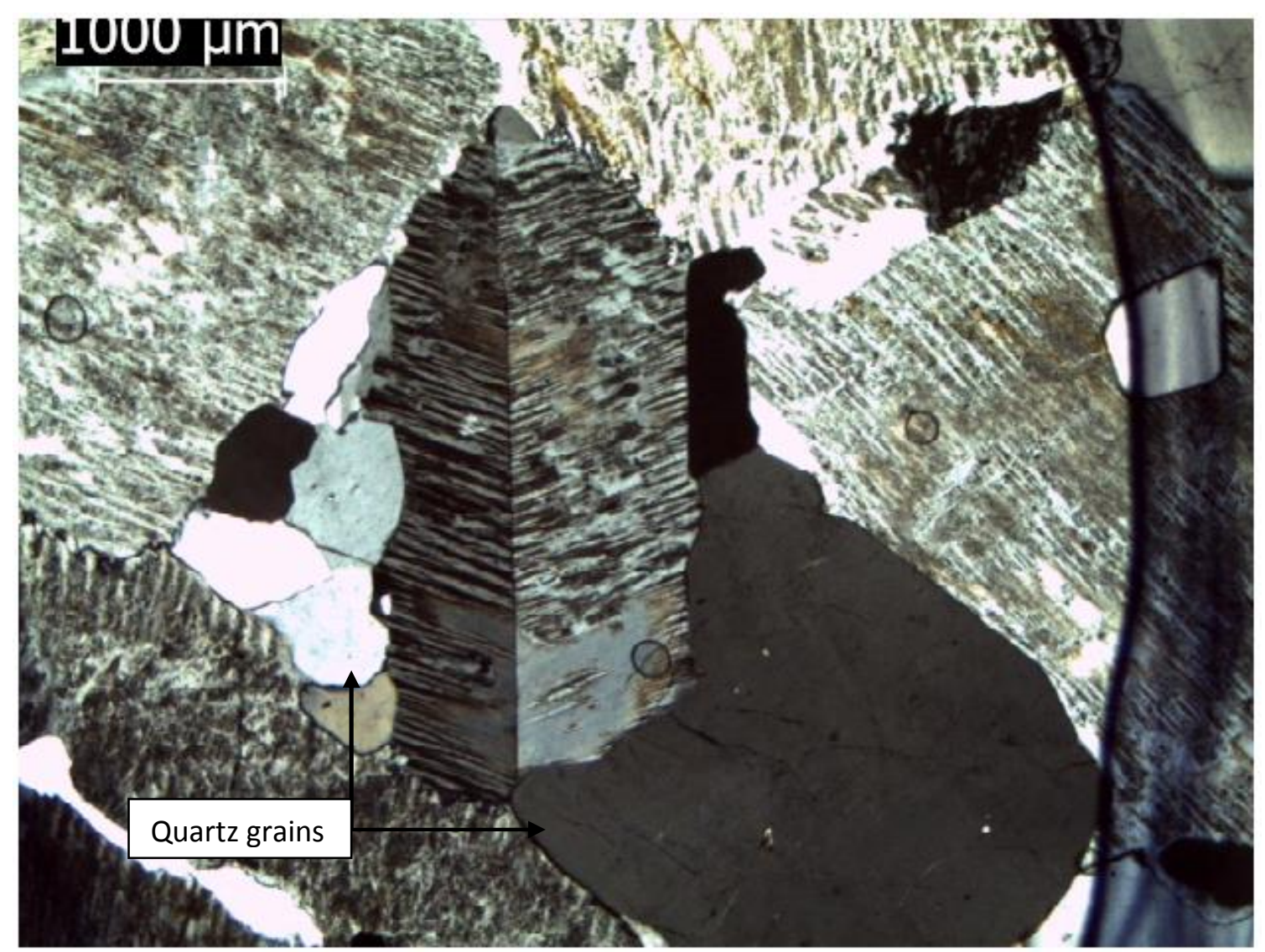

Figure 3. Thin section in cross polarization of alkaline granite. Note the Carlsbad twinning in potassium feldspar and the varying quartz size. 


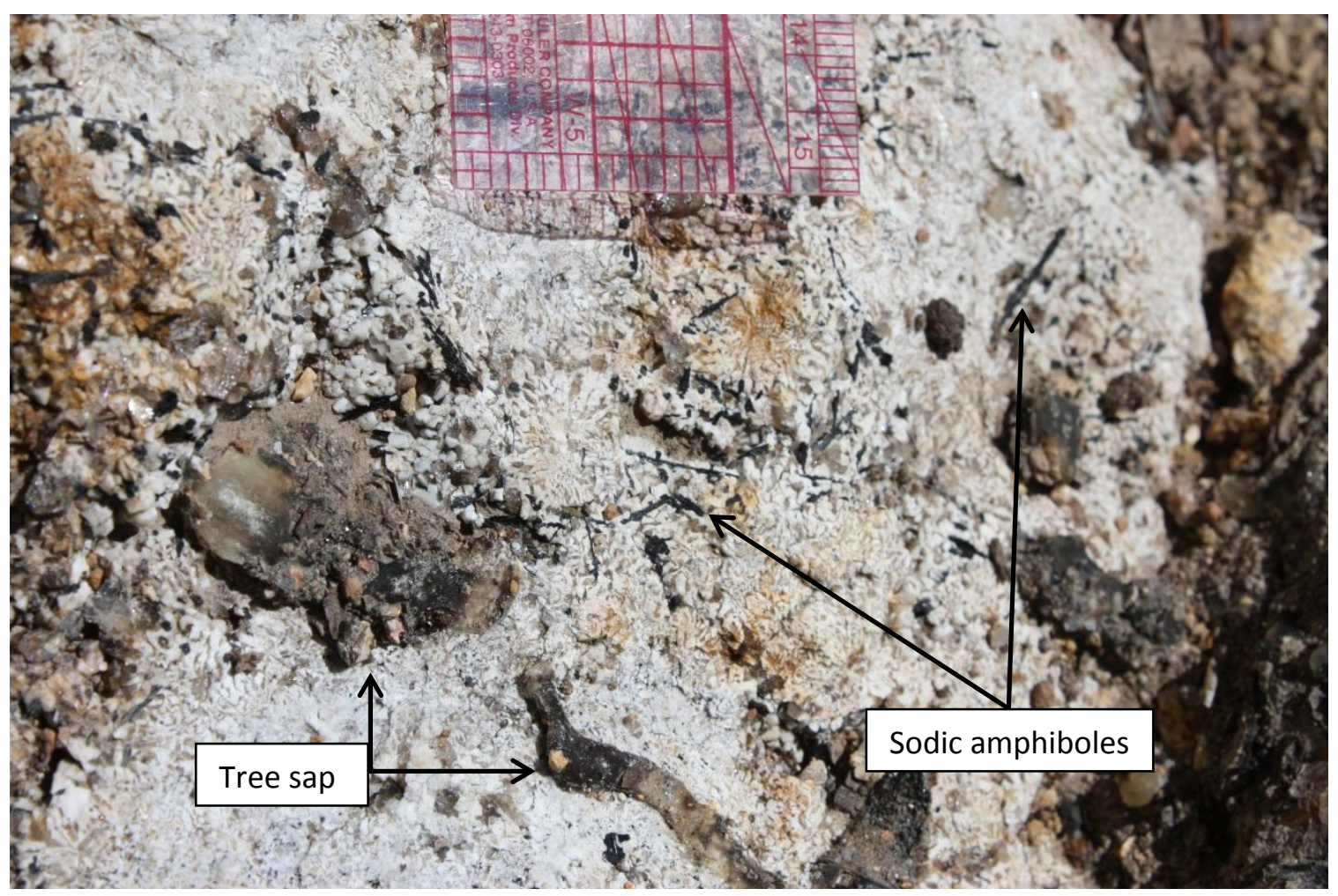

Figure 4. Alkaline granite containing sodic amphiboles. The dashes on the right side of the ruler are millimeters.

\section{One Feldspar-Biotite Granite}

The 48.2 $\pm 0.030 \mathrm{Ma}$ (Eddy et al., 2016a) one feldspar-biotite granite, or hypersolvus granite, is located north of the alkaline granite. This granite is structurally between the two feldspar-biotite granite and the alkaline granite (Fig. 2). It is heterogeneous compositionally across the batholith. Grain size ranges from sub-millimeter up to several centimeters, modes range having a majority of feldspar to even amounts of feldspar and quartz, and color index ranges from 5 to 15. This granite is equigranular, coarse-grained, and consists of quartz, perthite, biotite, and minor amounts of sodic amphibole (Fig. 5). It is most easily distinguished from the alkaline granite by the presence of biotite. The 
quartz is anhedral, embayed, and commonly rounded. The perthite has Carlsbad twinning and the biotite is chloritized in some places.

The gradational contact between the one feldspar-biotite granite and the two feldsparbiotite granite occurs over a distance of $\sim 3 \mathrm{~m}$. Rare $\sim 5-\mathrm{cm}$ - to 50 -cm-thick dikes of the one feldspar-biotite granite intrude the alkaline granite, establishing the relative ages of the units and in agreement with the $\mathrm{U}-\mathrm{Pb}$ ages. These dikes have relatively sharp boundaries, generally strike northwest, and have the largest variation in grain size in the batholith, as grains range from one millimeter to two centimeters in length.

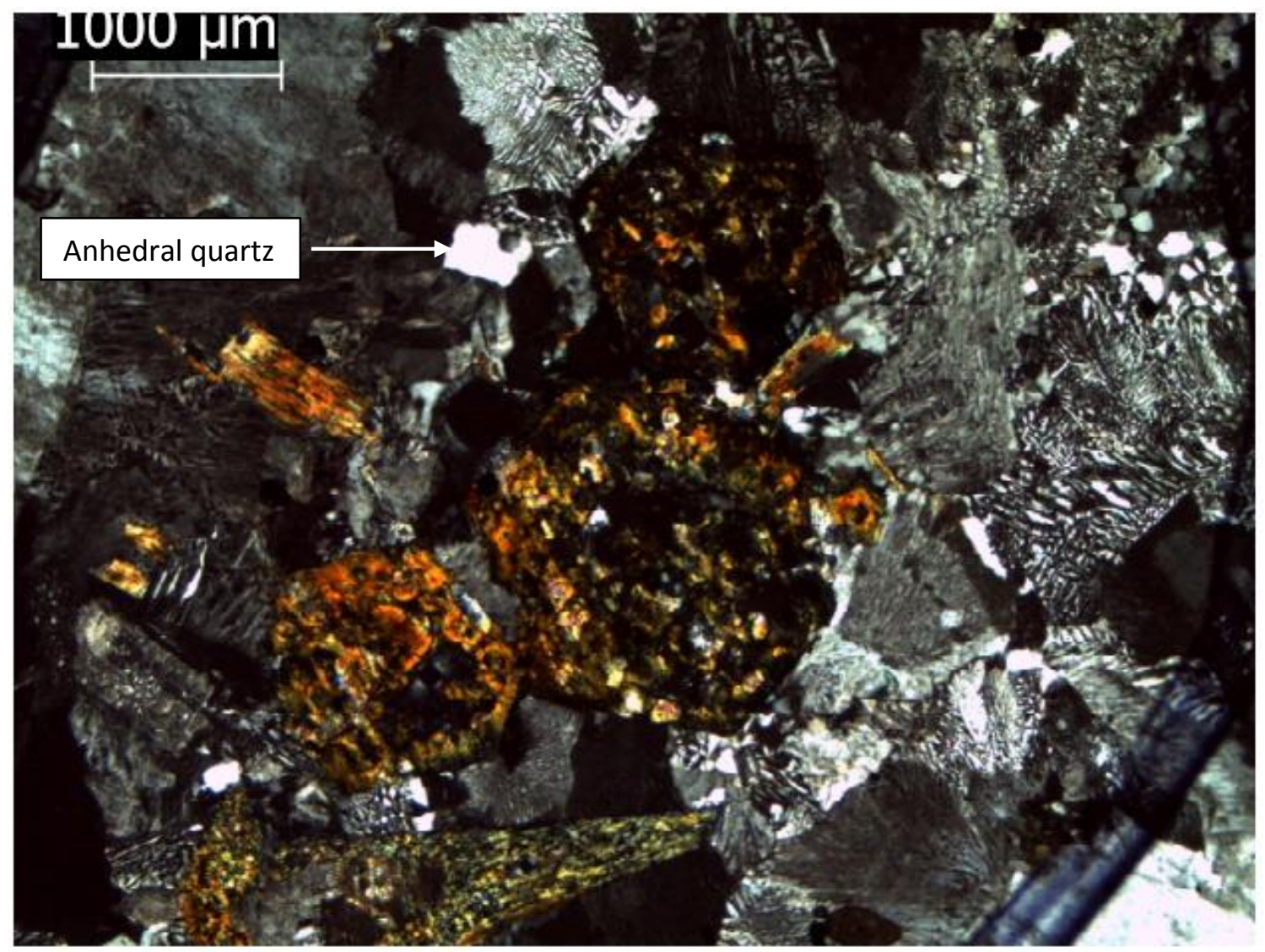

Figure 5. Thin section in cross polarization of one feldspar-granite showing biotite, myrmekite, and perthite. 
Microdiorite enclaves were observed rarely in this granite, consistent with the findings of Stull et al. (1987). Enclaves in the southeast part of the pluton range from 5 $\mathrm{cm}$ to $20 \mathrm{~cm}$ in length and aspect ratios range from $2: 1$ to $4: 1$. Some of these enclaves are porphyritic with plagioclase phenocrysts and have sharp boundaries on one side and more disaggregated contacts on the other (Fig. 6). The disaggregated sides have faint whisps of partially mixed or hybridized enclave mafic material away from the enclave.

\section{Two Feldspar-Biotite Granite}

The 48.139 $\pm 0.025 \mathrm{Ma}$ (Eddy et al., 2016a) two feldspar-biotite granite forms a $\sim 3$ $\mathrm{km}$ wide and $35 \mathrm{~km}$ long, NW-trending belt. The two feldspar-biotite granite is the largest rock unit of the Golden Horn batholith and volume estimates place the granite at $>424 \mathrm{~km}^{3}$ assuming it extends the length of the pluton (Eddy et. al., 2016a). It grades into the one feldspar-biotite granite to the south over a roughly one meter distance. The two feldspar-biotite granite consists of quartz, orthoclase, albite, biotite, and hornblende (Stull, 1969). Plagioclase is predominately euhedral albite, whereas the perthitic orthoclase is anhedral. The quartz is rounded, anhedral, embayed, and ranges in size from several millimeters to micrometers. Magnetite is observed on the rims of some hornblende crystals. 


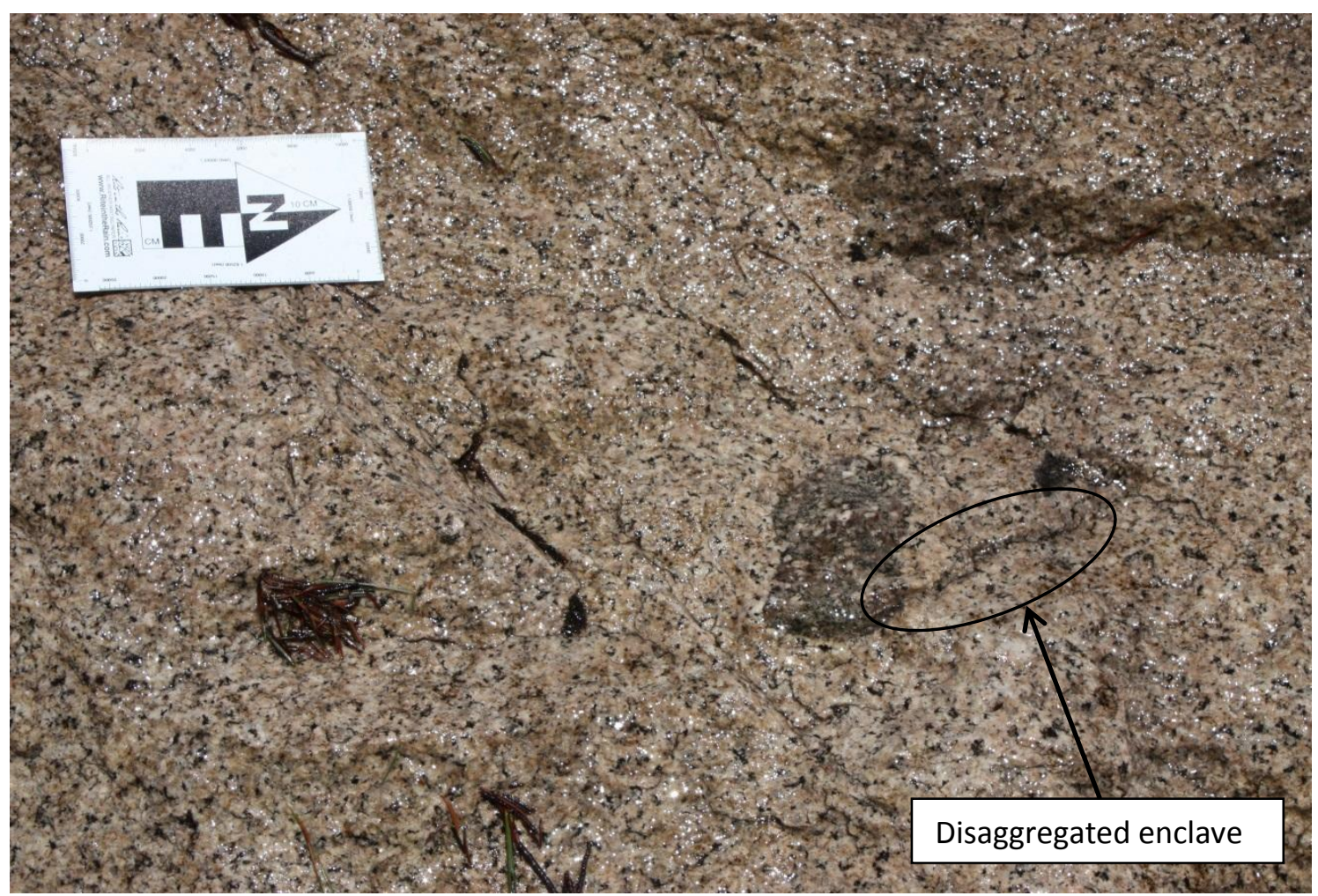

Figure 6. Mafic enclave in one feldspar-granite. Note the circled disaggregated enclave. The scale card is $15 \mathrm{~cm}$ long and $8.5 \mathrm{~cm}$ wide.

The two feldspar-biotite granite is characterized by a rapikivi texture of pink plagioclase-rimmed orthoclase. This texture is visible in hand sample, and micro-rapikivi texture is evident under the microscope. The variation in rapikivi size is accompanied by varying abundance of the texture, from tens of centimeter-sized crystals in thin section to only one or two in thin section (Fig. 7). The feldspars with rapikivi texture range from $\sim 1 \mathrm{~cm}$ to sub-millimeter. Several enclaves were observed in the two feldspar-biotite granite along Highway 20 near Lone Fir campground (Fig. 2). These enclaves are smaller than those in the one feldspar-biotite granite to the west, measuring from $2 \mathrm{~cm}$ to $8 \mathrm{~cm}$ in length and having aspect ratios from 1:1 to $3: 1$. Rare schlieren, defined by biotite and hornblende, occur near enclaves and are $\sim 1 \mathrm{~cm}$ wide and $\sim 10 \mathrm{~cm}$ long. 


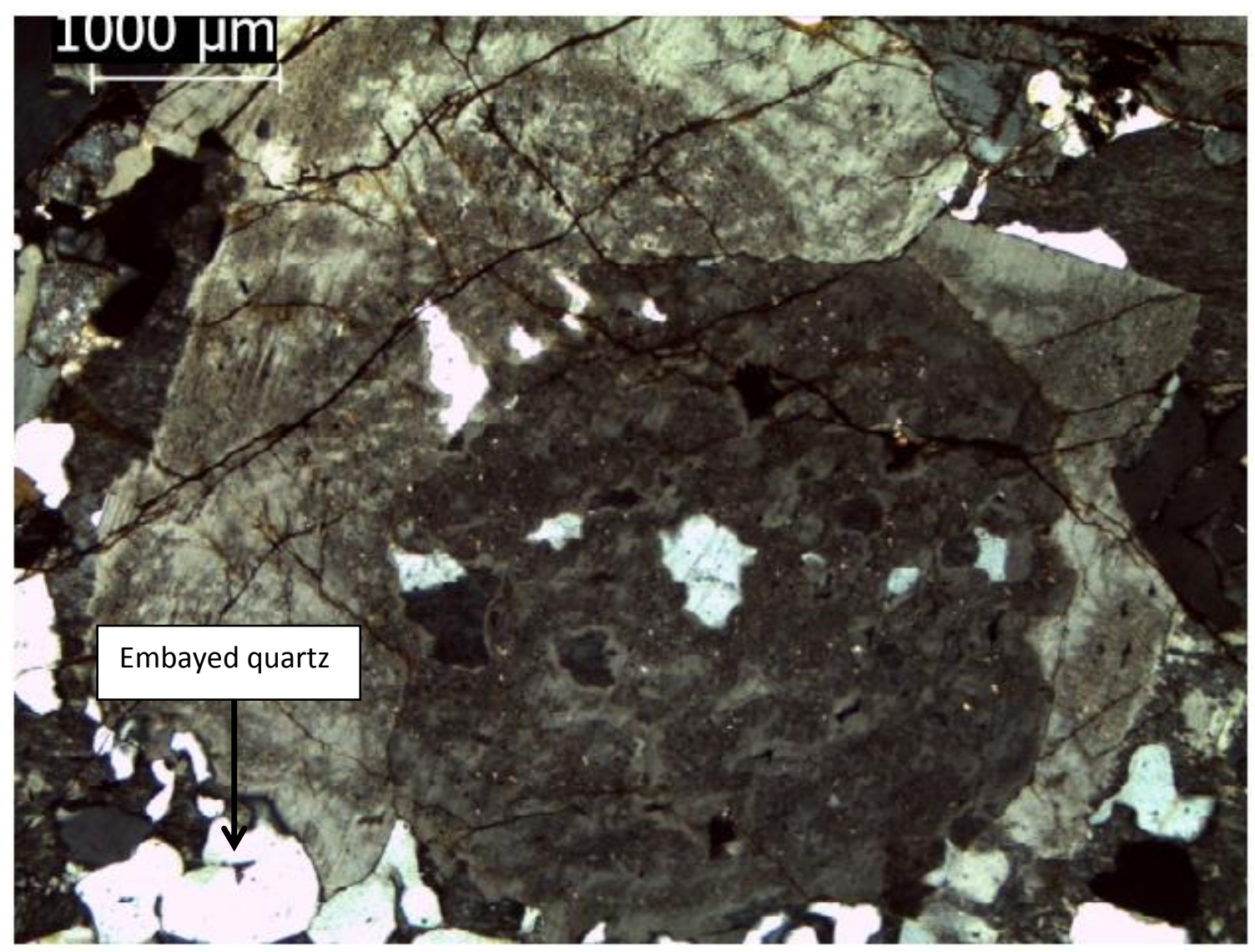

Figure 7. Thin section in cross polarization of two feldspar-granite showing rapikivi texture and embayed quartz. 


\section{Granodiorite}

Granodiorite was observed along Highway 20 in the northwest part of the batholith. These rocks are more mafic than most of the other units. The granodiorite is the youngest and structurally lowest unit within the Golden Horn batholith, has a date at 48.045 Ma \pm 0.034 , and has an estimated volume of $197 \mathrm{~km}^{3}$ (Eddy et. al., 2016a). The granodiorite is porphyritic, appears 'splotchy", and generally consists of a fine-grained matrix of quartz, plagioclase, biotite, hornblende, and phenocrysts of plagioclase. The biotite is tabular and chloritized, and plagioclase is sericitized. Rapikivi texture occurs rarely.

Enclaves in granodiorite in the NW part of the batholith range from $1 \mathrm{~cm}$ to $10 \mathrm{~cm}$ in length and have aspect ratios that vary from 6:1 to 1:1. They are generally fine-grained and equigranular. Plagioclase phenocrysts, similar in size and shape to those in the host granodiorite, are present within some of the enclaves and appear to be incorporated from the surrounding coarser-grained host (Fig. 8). Schlieren defined by biotite and hornblende are associated with groups of enclaves. These schlieren are from $8 \mathrm{~cm}$ to $2 \mathrm{~m}$ in length and 3 to $10 \mathrm{~cm}$ in width. 


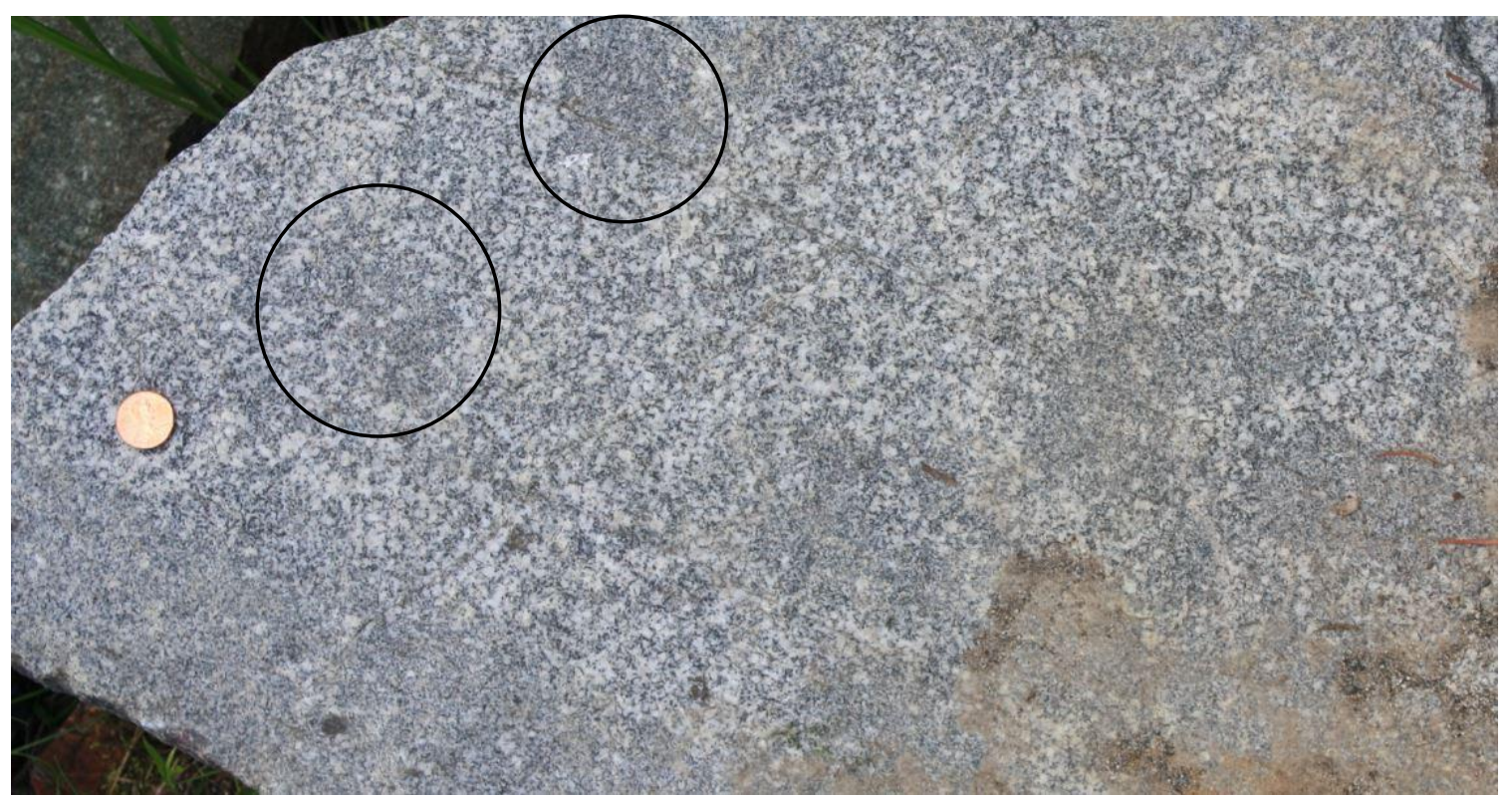

Figure 8. Mafic granodiorite talus near the northwest end of the batholith. Note the circled enclaves and their disaggregated edges. The "splotchy" appearance suggests hybridization. The penny for scale is $2 \mathrm{~cm}$ wide.

\section{Fabrics}

The Golden Horn batholith contains two foliation orientations. The dominant foliation is NW-striking and typically SW-dipping, and the weaker foliation is NEstriking with both NW and SE dips (Fig. 9). Both foliations are defined by biotite and hornblende in the one and two feldspar-biotite granites, and by sodic amphibole in the alkaline granite. Both foliations are also considerably weaker in the alkaline granite and are more difficult to detect due to the only minor amounts of mafic minerals. Dips of both fabrics are moderate to steep, and are generally $>60^{\circ}$.

The NW-striking foliation is observed throughout the batholith and cross-cuts the sub-horizontal internal contacts between units of the batholith. Foliation observed at the northwestern contact and part of the southern contact (North Creek Trail) appears discordant to the batholith contact (Figs. 2 and 10). South and west of Washington Pass, 
the foliation is concordant with the batholith contact (Figs. 2 and 10). Foliation does not appear to steepen significantly in the granodiorite unit of the batholith toward the contact with the Ruby Creek heterogeneous plutonic belt. Similarly, foliation dip does not change significantly as the southern and southeastern contacts are approached.

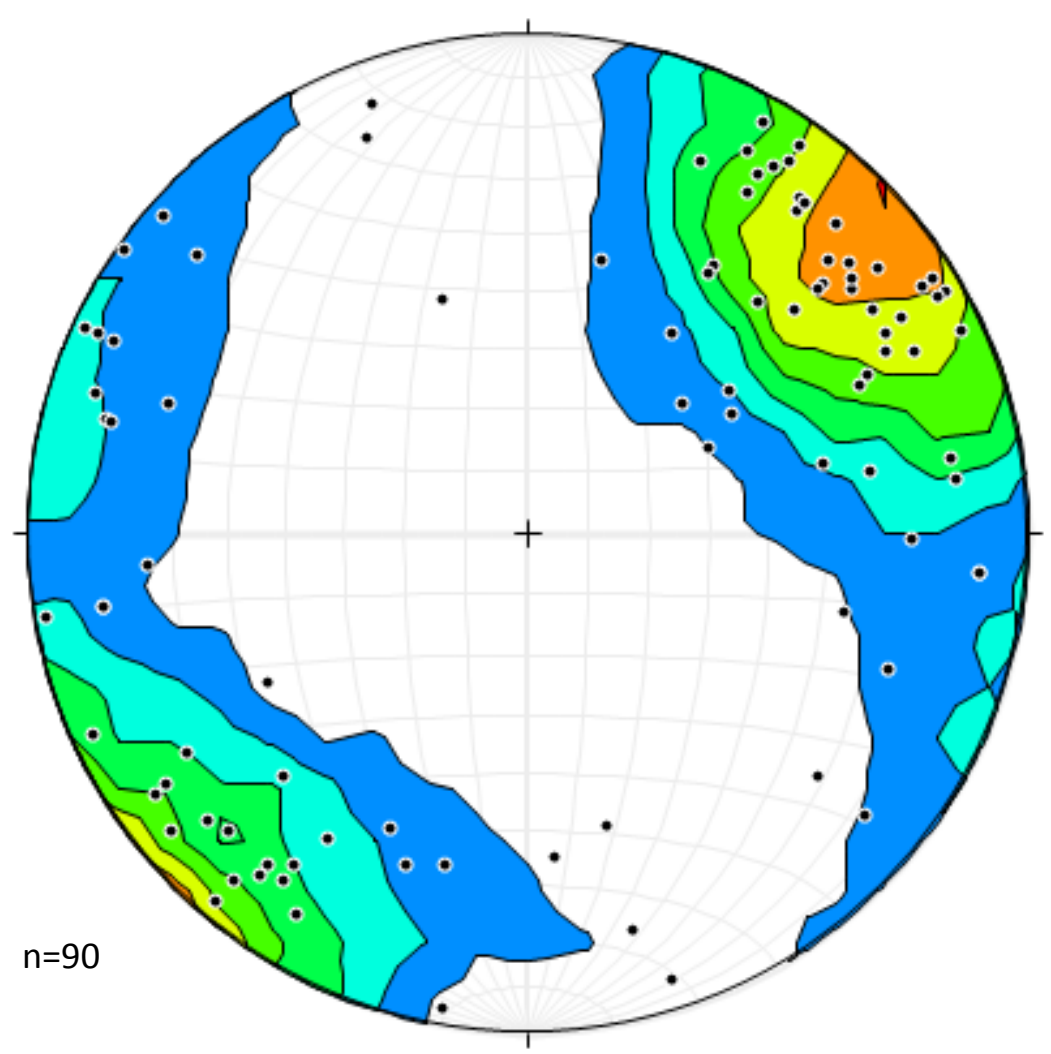

Figure 9. Poles to magmatic foliations within the Golden Horn batholith. Poles projected onto a lower-hemisphere stereograph. Contour interval is 2 sigma using the Kamb (1959) method. 


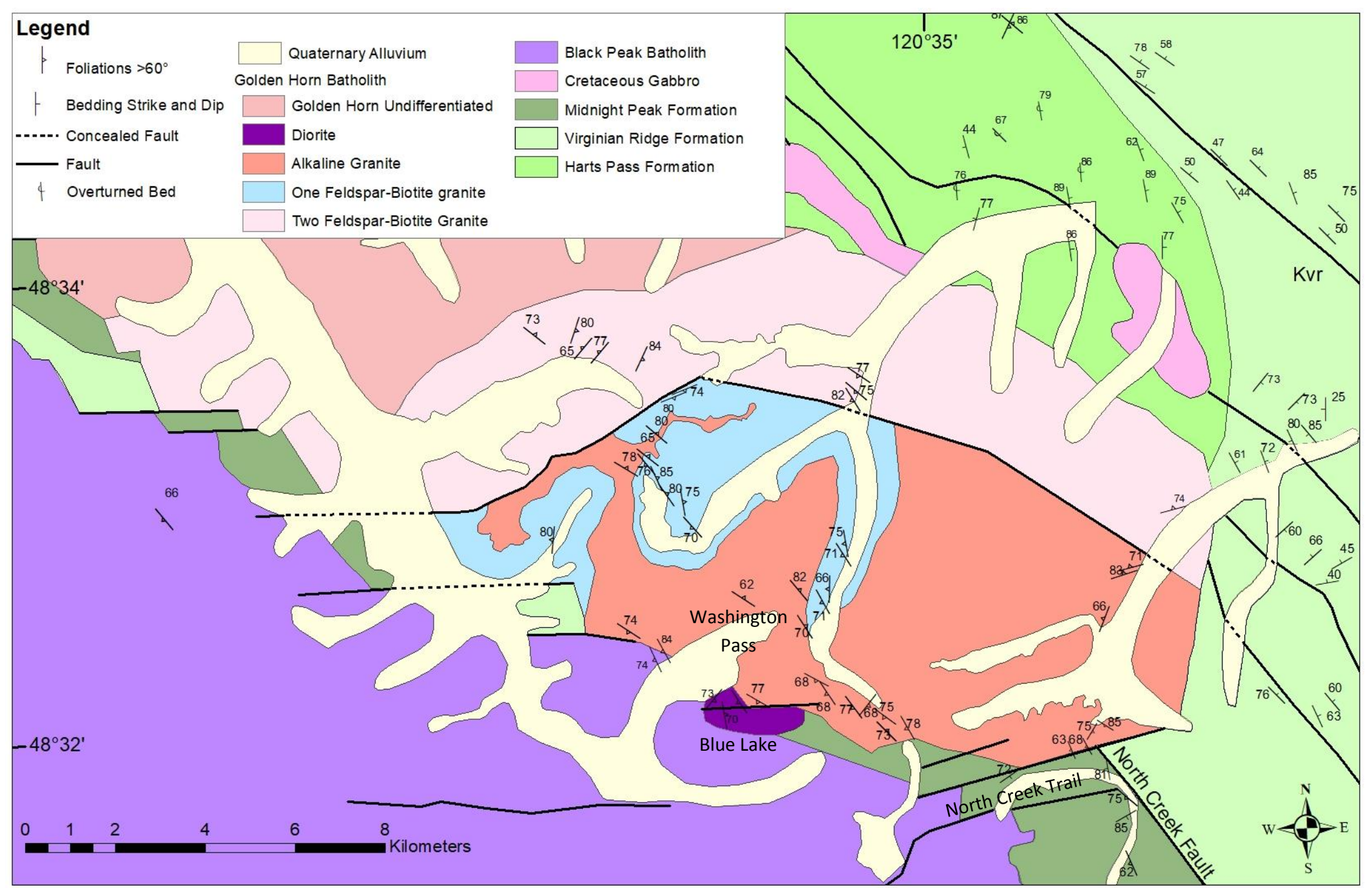

Figure 10. Map of the southern half of the Golden Horn batholith showing internal foliation and host rock foliation and bedding. Some host rock measurements are based on mapping of McGroder et al. (1990). 
The weaker NE-striking foliation is centrally located within the batholith in the two feldspar-biotite granite (see Geologic Setting, Fig. 2). There is also a weak NW-trending lineation across the batholith that is defined by biotite and hornblende, and plunges $<30^{\circ}$.

Minor grain boundary migration and recrystallization of quartz were observed in thin sections from each rock type and from different parts of the batholith. This is compatible with weak solid-state deformation and the lack of solid-state foliation.

\section{Host Rock Foliations and Beds}

Foliations were measured for several hundred meters into the host rock to the east, south, and southeast of the batholith and supplemented by measurements of previous workers (McGroder et al., 1990; Dragovich et al., 2002). Beds to the east in the Virginian Ridge, Midnight Peak, and Harts Pass formations of the Methow basin are predominantly north- and northwest-striking, and dip roughly $60^{\circ}$ or more to the northeast and southwest (Fig. 10). The metasedimentary and metavolcanic rocks to the south and west of Washington Pass exhibit a NW-striking foliation with average dips of $72^{\circ}$ to the NE and SW. To the south along the North Creek Trail, most foliations and beds strike NW and have average dips of $70^{\circ} \mathrm{SW}$ in the Cretaceous metavolcanic and metasedimentary and rocks of the Midnight Peak and Virginian Ridge Formations, respectively. No deflection of foliation was observed as the contact with the Golden Horn batholith was approached.

\section{Dikes}

Dikes associated with the Golden Horn batholith intrude the batholith and the host rock near the batholith. These dikes have been described by previous workers (Misch, 
1966; Tabor et al., 1968). Dikes have been grouped into three types: aplite dikes, porphyritic dikes, and mafic dikes.

\section{Aplite Dikes}

Aplite dikes of the one and two feldspar-biotite granite are abundant in the Golden Horn batholith, and mostly intrude the alkaline granite unit. Intermediate and mafic dikes are less common. Aplite dikes are typically $\sim 1 \mathrm{~m}$ in thickness, but range from $\sim 10 \mathrm{~cm}$ to $\sim 2 \mathrm{~m}$ in width, and strike $\mathrm{W}$ to $\mathrm{NW}$ with dips from 15 to $45^{\circ}$ to the $\mathrm{N}$ and NE (Fig. 11). Most aplite dikes were only traced for $\sim 5 \mathrm{~m}$ due to limited outcrop exposure and dense vegetation at the locations mapped. Marginal mafic concentrations of biotite, which are $\sim 1 \mathrm{~cm}$ thick, and miarolitic cavities, which are 2 to $5 \mathrm{~mm}$ in diameter, are common features of the aplite dikes.

\section{Porphyry Dikes}

Rapikivi porphyry dikes interpreted to be related to the batholith intrude the host rocks in several locations, including near Silent Lakes to the west, the Cedar Creek Trail to the south, the Methow River to the west, and along Highway 20 west of Washington Pass (see Geologic Setting, Fig. 2). In addition, north of Cutthroat Pass along the Pacific Crest Trail, two distinct rapikivi porphyry dikes intrude the one feldspar-biotite granite. These two bodies are roughly $35 \mathrm{~m}$ wide, strike $\mathrm{SW}$, dip $85^{\circ} \mathrm{NW}$, and extend for at least $50 \mathrm{~m}$. 


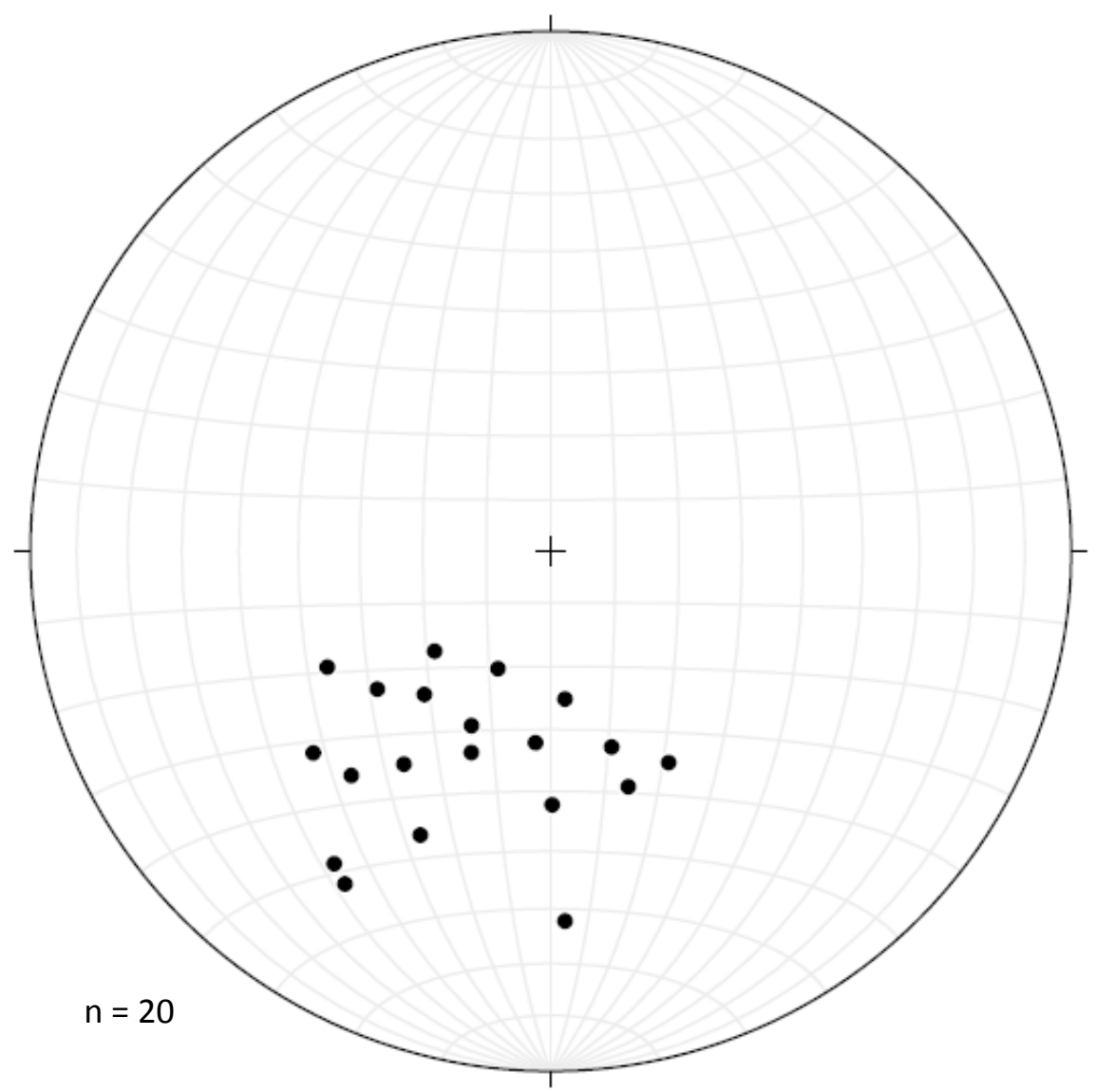

Figure 11. Stereographic projection of poles to planes of aplite dikes. 
Phenocrysts in Golden Horn porphyry dikes are $1 \mathrm{~cm}$ in length and include embayed quartz, plagioclase, and rapikivi feldspar. The phenocrysts are enclosed by a fine-grained matrix of myrmekite and spherules of devitrified glass. The only mafic mineral is biotite in trace amounts, and it is partially altered to chlorite. There is much scatter on a stereographic projection, but the general strike of porphyry dikes is west-northwest, and dips are generally $>60^{\circ}$ to both the north-northeast and south-southwest (Fig. 12). Rapikivi porphyry dikes commonly have sharp, chilled boundaries with a $\sim 3 \mathrm{~cm}$ - to 10 cm-wide, fine-grained margins (Fig. 13).

\section{Mafic Dikes}

Mafic dikes were observed in several locations next to the Golden Horn batholith and are inferred to be related to the pluton. These mafic dikes intruded to the west and south into the Black Peak batholith, and into metasedimentary and metavolcanic rocks of the Virginian Ridge and Midnight Peak Formations, respectively.

Mafic dikes also intrude the sedimentary rocks of the Methow basin to the north along the Methow River Trail and Harts Pass Road (Figs. 14 and 15). These mafic dikes are fine-grained and consist of biotite, hornblende, plagioclase, orthoclase, and minor quartz. Some are equigranular, whereas others contain plagioclase phenocrysts. Finegrained mafic dikes in a road cut along Highway 20 west of Blue Lake intrude the Black Peak batholith and range in width from tens of $\mathrm{cm}$ to $8 \mathrm{~m}$. 


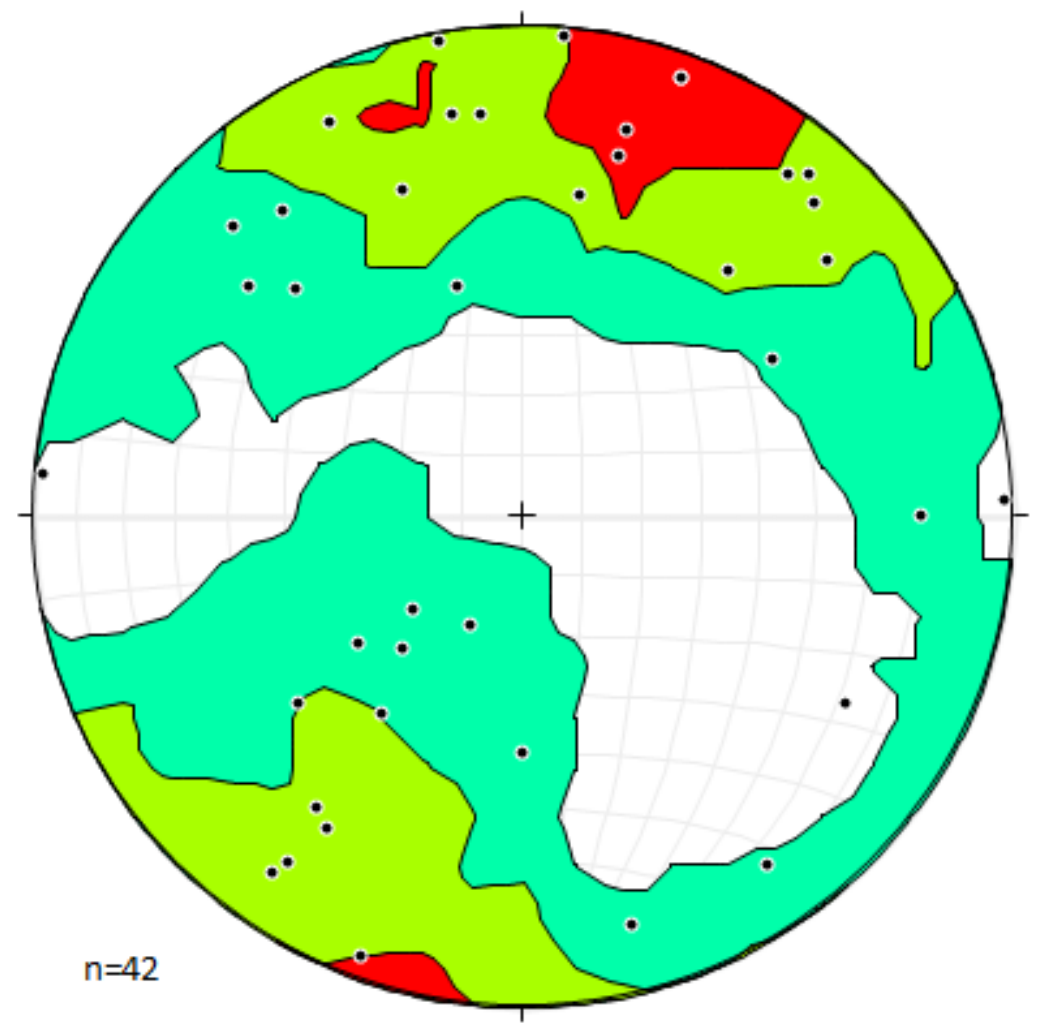

Figure 12. Poles to porphyry and mafic dikes. Poles projected onto a lower-hemisphere projection. Contour interval is 2 sigma using the Kamb (1959) method. 


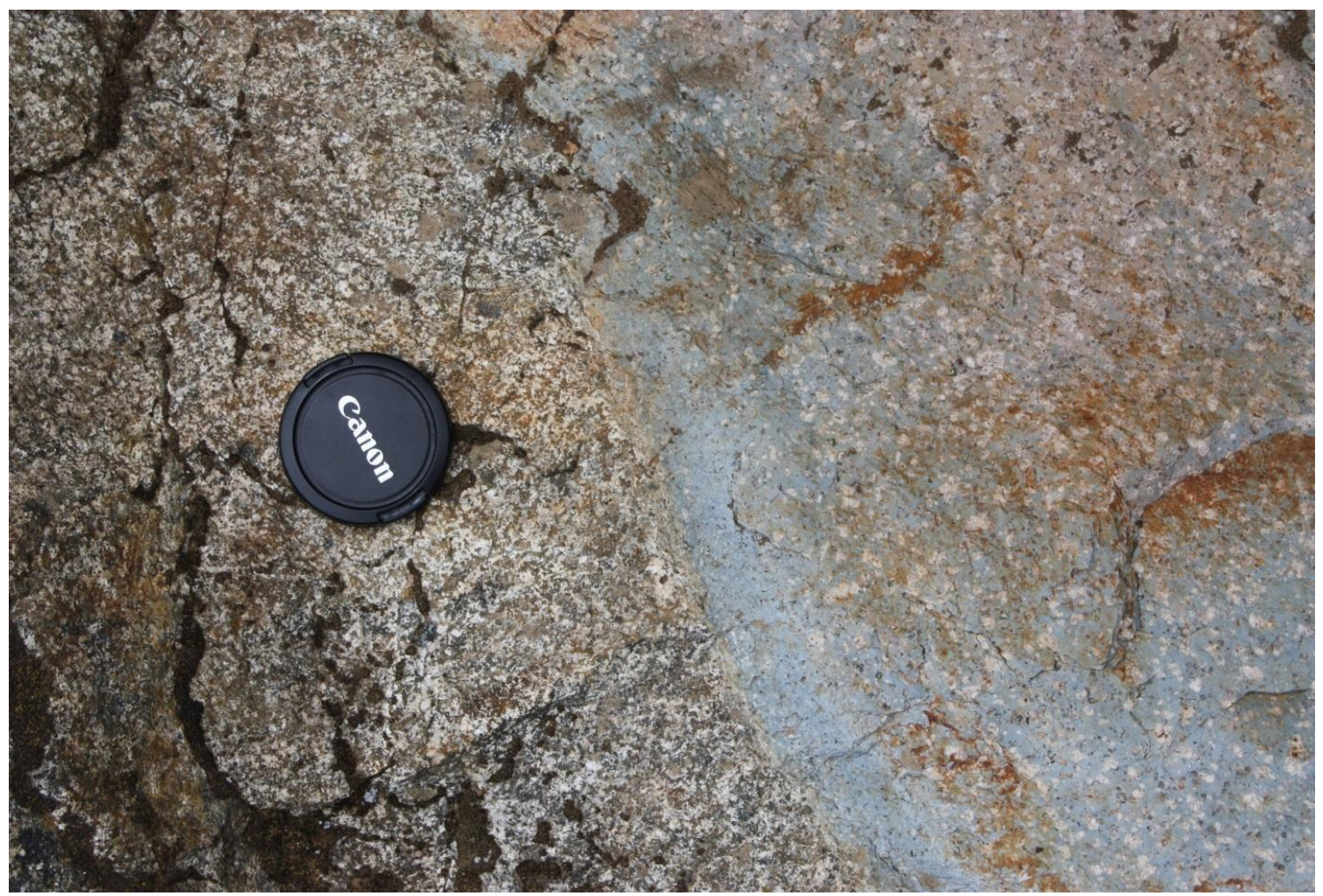

Figure 13. Outcrop of rapikivi porphyry dike. Rapikivi porphyry (right side) intruded one feldspar-biotite granite along the Pacific Crest Trail near Cutthroat Pass. Note the $\sim 4$ $\mathrm{cm}$ wide, chilled margin that lacks the larger orthoclase crystals in the dike interior. The camera lens cap is $8 \mathrm{~cm}$ wide. 


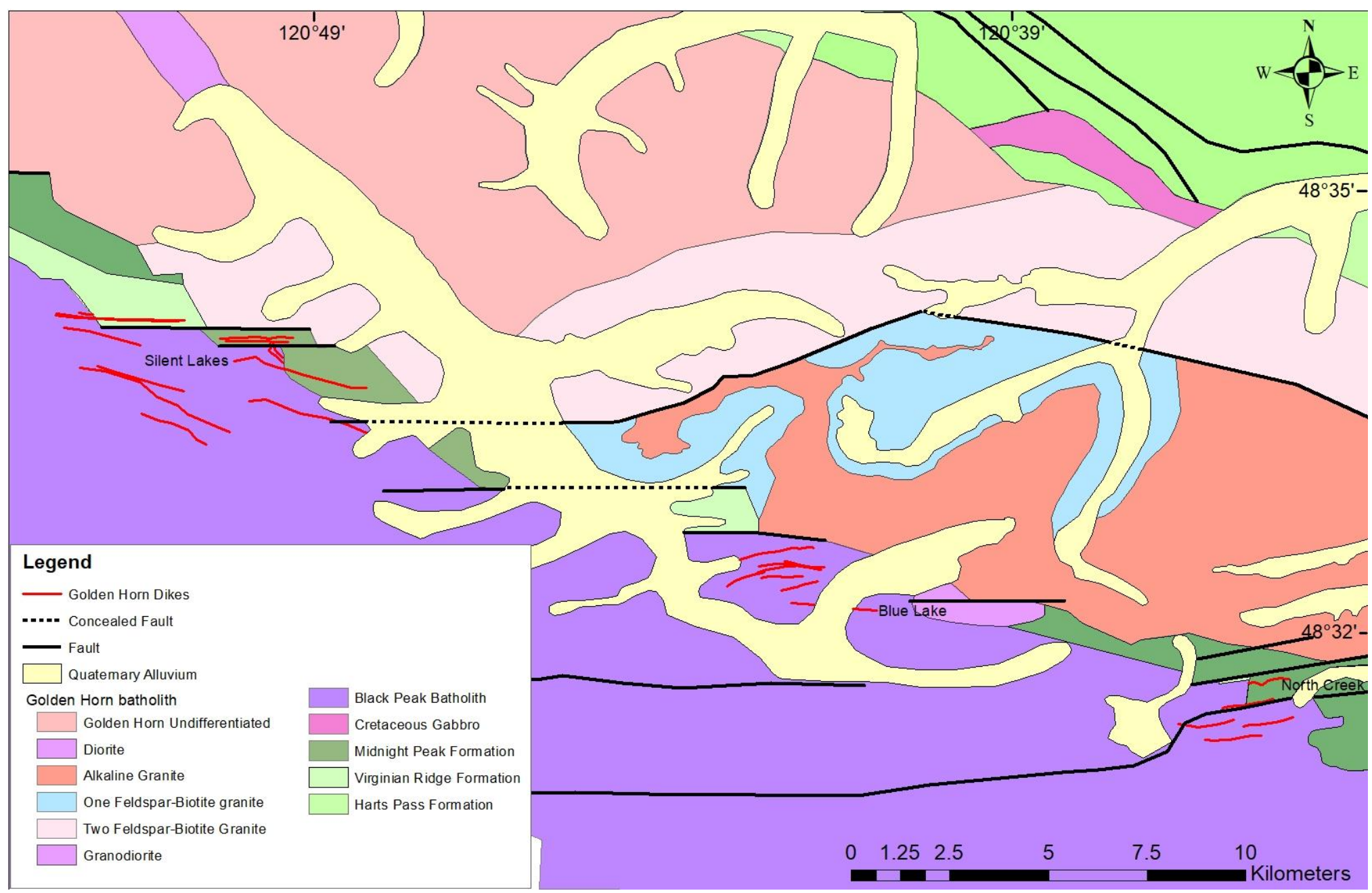

Figure 14. Simplified map showing Golden Horn dikes intruding host rock near the southern and southwestern contact of the Golden Horn batholith. 


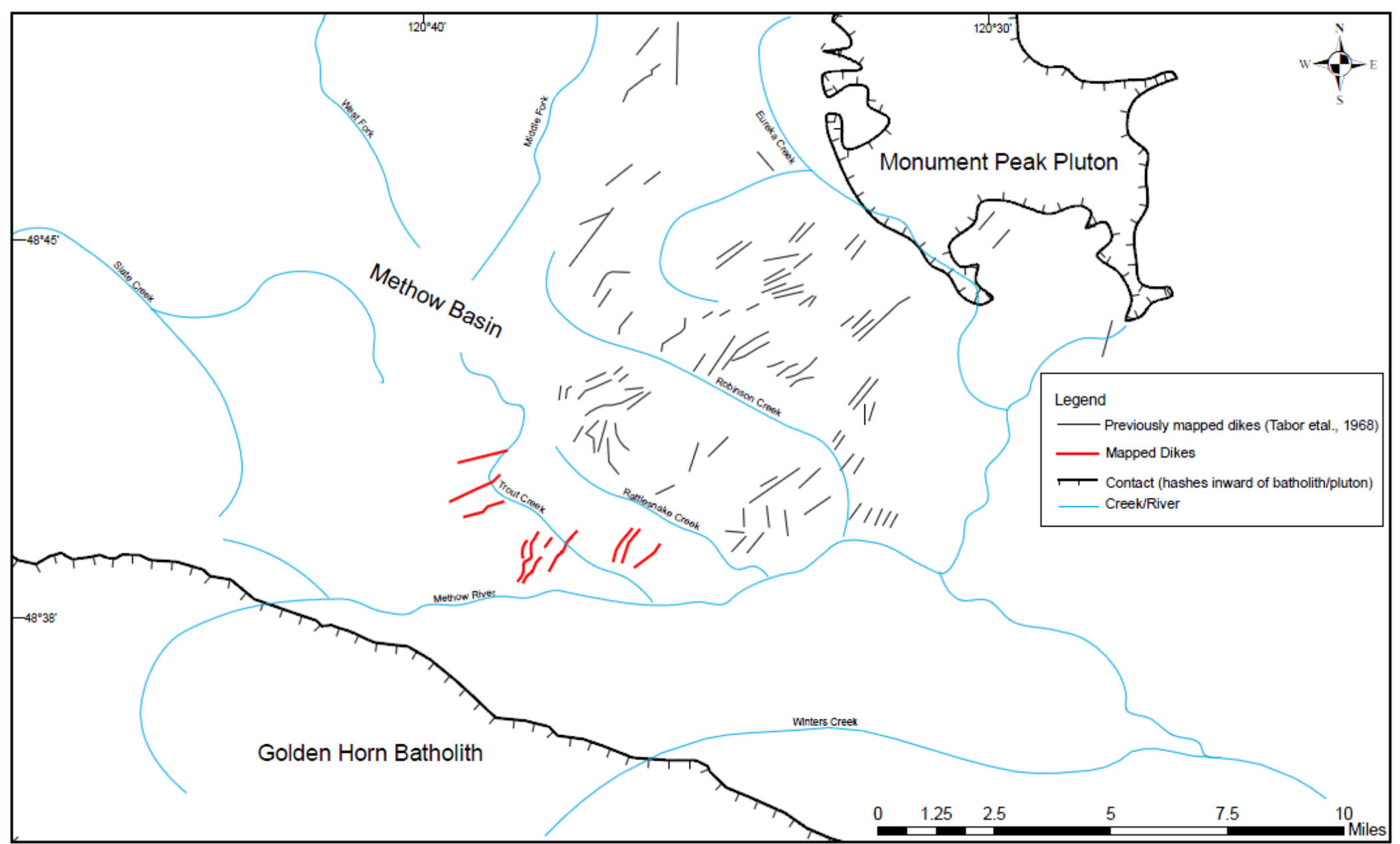

Figure 15. Simplified map showing dikes between the Golden Horn batholith and the Monument Peak pluton. Contacts are from Tabor et al., 1968. 
The mafic dikes at Silent Lakes and west of Blue Lake intrude the Black Peak batholith, and they extend for as long as $3 \mathrm{~km}$ (Fig. 16). The dikes range in width from centimeters to 5 meters, and generally strike east-west and dip to the north. To the NE of the batholith, mafic dikes intrude the Harts Pass Formation as far as $5 \mathrm{~km}$ from the batholith (Fig. 15).

Golden Horn dikes intruding the Midnight Peak and Virginian Ridge Formations were measured near Harts Pass Road, roughly $8 \mathrm{~km}$ north of the batholith, by Robert Miller (written communication). These dikes have an average NE trend $\left(024^{\circ}\right)$, and all have steep dips to the east and west $\left(>75^{\circ}\right)$. Tabor et al. (1968) mapped dikes near the 48 Ma Monument Peak pluton, which is roughly $17 \mathrm{~km} \mathrm{NE}$ of the Golden Horn batholith (Fig. 15). The dikes mapped by Tabor et al. (1968) are quartz porphyries, which occur in swarms and strike predominately NE.

\section{Faults}

The Golden Horn batholith intrudes the NW-striking Ross Lake fault zone. To the north and southeast of the batholith there are NW-trending strike-slip faults (Dragovich et al., 2002). The major northern fault is the Hozameen fault, which place prehnitepumpellyite-facies Hozameen Group against amphibolite-facies migmatites of the Skagit Gneiss Complex (Misch, 1966; Haugerud, 1985). To the southeast, the North Creek fault separates non-metamorphosed sedimentary and volcanic rocks of the Methow basin to the northeast from low- to intermediate-grade metamorphic rocks of the same formations to the southwest (McGroder et al., 1990) (Fig. 17). The Hozameen fault and the North Creek fault are truncated by the batholith. 


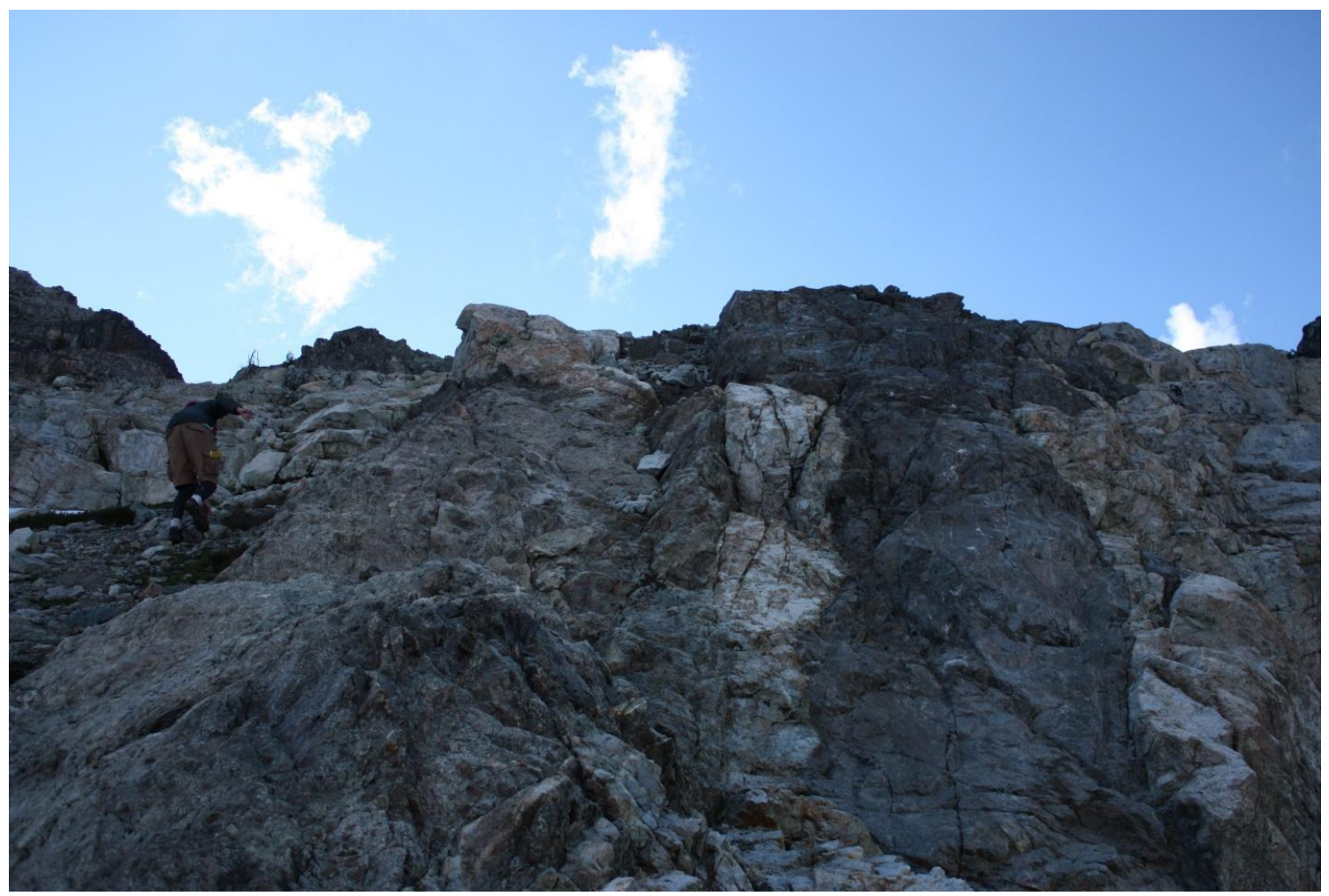

Figure 16. Photo facing west of two mafic Golden Horn dikes intruding the Black Peak batholith at Silent Lakes. The dikes are $\sim 4 \mathrm{~m}$ and $2 \mathrm{~m}$ wide on the left and right, respectively. Note the person to the left in the photo for scale. 


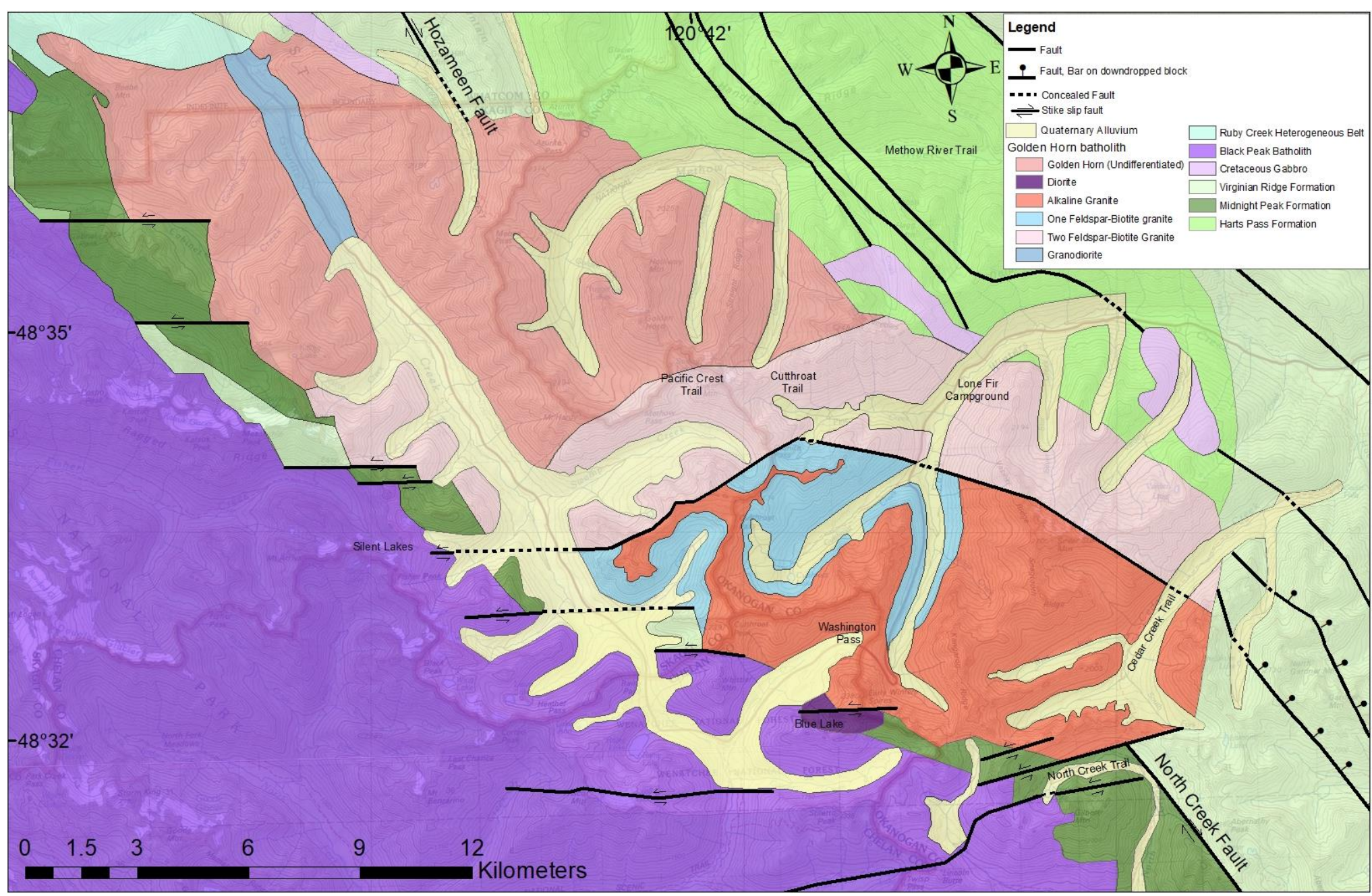

Figure 17. Simplified map of faults to the north, east, and south of the Golden Horn batholith. Map includes faults from Dragovich et al. (2002) and McGroder et al. (1990). 
The western and southwestern contacts of the batholith are cut by several E-Wtrending faults (Dragovich et al., 2002). Strike separation on these faults ranges from 0.5 $\mathrm{km}$ to $2.5 \mathrm{~km}$ and the sense of separation of the Golden Horn-host rock contact is sinistral. These strike-slip faults range from $3 \mathrm{~km}$ to $9 \mathrm{~km}$ in length and step north and west along the batholith contact towards a stepover within the Ross Lake fault zone (Miller et al., 1994; Gordon et al., 2010).

\section{CONTACTS WITH HOST ROCKS}

The Golden Horn batholith intruded into sedimentary, metasedimentary, metavolcanic, and igneous host rocks. This section describes contacts with the host rocks.

\section{Northwestern Contact}

To the northwest, the Golden Horn batholith is in contact with a belt of igneous intrusions that Misch (1966) called the Ruby Creek heterogeneous plutonic belt. The ca. 48 Ma Ruby Creek plutons (Miller et al., 2016), most of which are tonalite, intrude phyllite and schist of the Little Jack unit. Some of the tonalite also resembles the Cretaceous Black Peak batholith (Haugerud and Tabor, 2009).

A 180-200 m transition zone was observed between the granodiorite of the Golden Horn batholith and the main Ruby Creek outcrop. This transition zone is comprised of tens-of-meters-wide zones of phyllite, schist, and Golden Horn dikes before entering tonalite, which makes up much of the Ruby Creek heterogeneous plutonic belt. The Golden Horn dikes are porphyritic, and a fine-grained matrix encloses quartz phenocrysts ranging up to one centimeter in width. Hornblende in the Golden Horn granodiorite is 
strongly aligned and defines a foliation that dips steeply to the west and southwest. Foliation in the metasedimentary rocks strikes $\mathrm{N}$ to $\mathrm{NW}$, dips greater than $75^{\circ}$, and is coupled with the NW-striking foliation in the Golden Horn batholith (Figs. 2 and 10).

\section{Eastern Contact}

To the east and northeast, the Golden Horn batholith is in contact with Cretaceous rocks of the Methow basin, including the Midnight Peak Formation, Virginian Ridge Formation, and Harts Pass Formation. The two feldspar-biotite granite is chilled against the host rock. To the southeast, the alkaline granite is in contact with metasandstones and metavolcanic rocks of the Virginian Ridge and Midnight Peak Formations (Fig. 10). This contact was not directly observed. Along the Cedar Creek Trail, bed dips range from $40^{\circ}$ to $80^{\circ}$ to the $\mathrm{SW}$ and $\mathrm{NE}$, and strikes are north-northwest, roughly parallel to the batholith contact. Northeast of the batholith, beds strike predominantly NW, are locally folded along NW-trending axes, and are overturned within $4 \mathrm{~km}$ of the batholith (McGroder, 1989).

\section{Southern Contact}

To the south, the Golden Horn batholith is in contact with the Black Peak batholith and the Midnight Peak and Virginian Ridge Formations. The Black Peak batholith is 92-88 Ma tonalite, granodiorite, and diorite (Adams, 1964; Shea et al., 2016), and is intruded by the alkaline granite of the Golden Horn batholith. South of Washington Pass, the alkaline granite and xenoliths of the Midnight Peak Formation form an approximately 100-m-wide zone of intrusive breccia (Misch, 1966). Xenoliths in this zone range in size from meters to decimeters, with an average of a few meters (Fig. 18). The xenoliths are 
sharp and angular blocks that chilled the alkaline granite around them. Southeast of Washington Pass along the North Creek trail, beds and foliation in the host rock are discordant to the ENE-trending Golden Horn batholith contact.

Approximately $25 \mathrm{~km}$ to the northwest near Easy Pass, another xenolith-rich zone of metasedimentary rocks occurs in the batholith at the southern contact with probable metamorphosed Virginian Ridge Formation (see Geologic Setting, Fig. 2). In this 200$\mathrm{m}$-wide zone, xenoliths have an average length of $3 \mathrm{~m}$, are angular, and are enclosed within the two feldspar-biotite granite. These xenolith-rich zones occur near the E-Wtrending, sinistral strike-slip faults described in Dragovich et al. (2002). The southern contact was not observed elsewhere and it is unclear whether xenoliths are ubiquitous along this contact. 


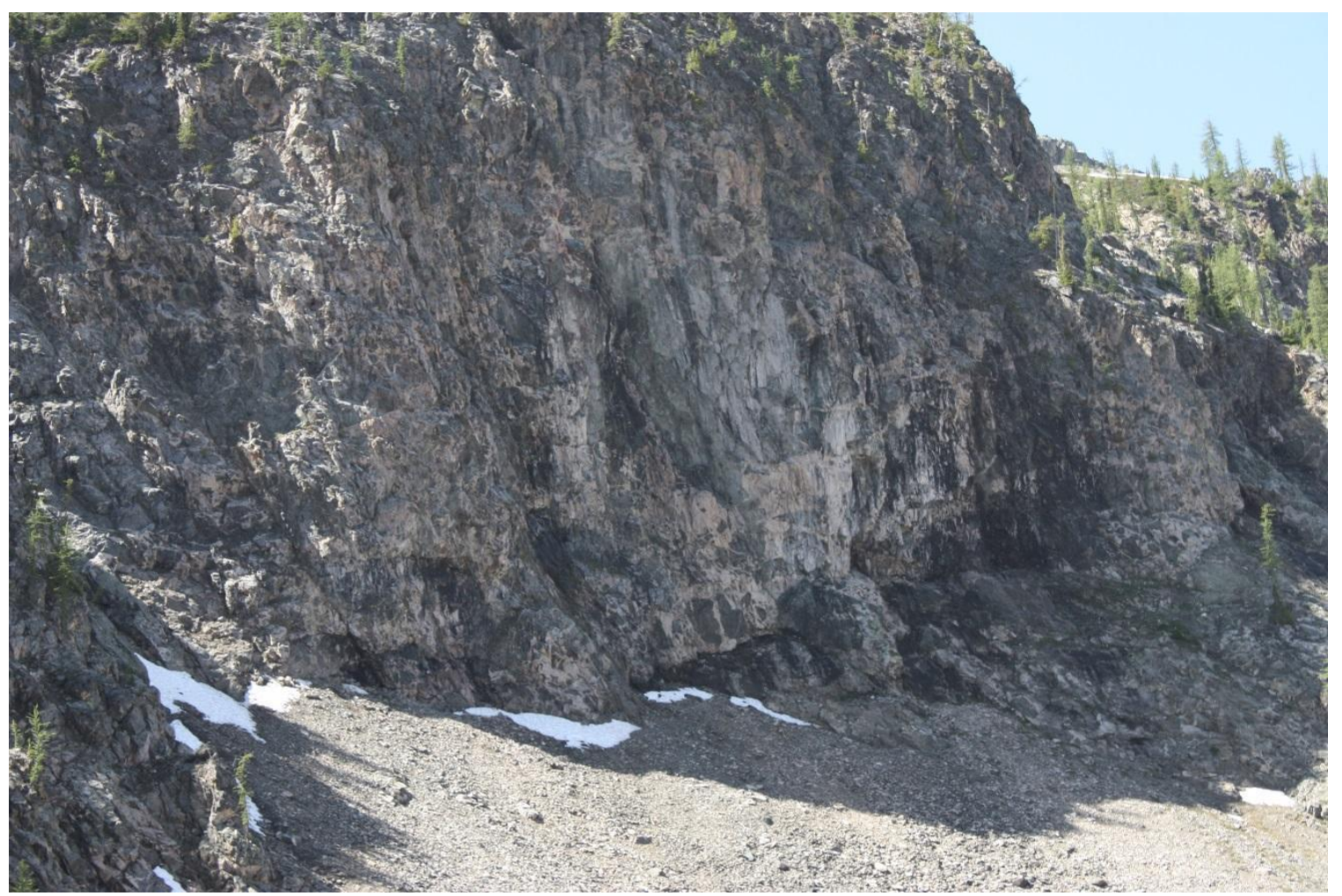

Figure 18. Xenoliths of metavolcanic rocks of the Midnight Peak Formation near Washington Pass. Outcrop is $~ 200 \mathrm{~m}$ away, $~ 50 \mathrm{~m}$ high and $60 \mathrm{~m}$ wide.

\section{DISCUSSION}

\section{Emplacement of the Golden Horn Batholith}

As magma ascends through the crust, the volume of the crust does not increase except where the Earth's surface is uplifted or the base of the crust is depressed. Therefore, magma emplacement is generally accomplished through material transfer processes. These processes include ductile flow, stoping, floor subsidence, magma wedging, roof uplift, and fault dilation (e.g., Hutton, 1992; Paterson et al., 1996). 


\section{Ductile Flow}

Ductile flow is typically observed in the deeper crust, but has also been observed in plutons emplaced in the shallow crust (e.g., Hutton, 1988; Morgan et al., 1998). Bedding observed within $\sim 300 \mathrm{~m}$ of the southeast contact of the batholith within the Cretaceous sedimentary rocks of the Methow basin strikes roughly northwest and dips steeply, and strikes do not rotate as the batholith contact is approached. Bedding east of the batholith is overturned away from the batholith contact, but overturned beds were mapped up to 20 km away from the batholith contact within the Methow basin (McGroder, 1989; McGroder et al., 1990), suggesting they probably represent Cretaceous regional folding. Thus, there is no direct evidence for ductile flow.

The contact of the batholith with Cretaceous metavolcanic rocks of the Midnight Peak Formation to the south and southwest is marked by meter- to decimeter-sized xenoliths of the host rock. It is unlikely that an earlier ductile structural aureole was removed through stoping, as the xenoliths do not show more strain than that of the intact host rock.

In the northwest, the host rock is devoid of a structural aureole. Foliation is parallel and consistent across several rock types within the Ruby Creek heterogeneous plutonic belt, and into the batholith. Thus, it appears that ductile flow was not an important mechanism, although it cannot be ruled out that a structural aureole is present next to parts of the batholith that were not studied.

\section{Stoping}

Stoping is one of several material transfer processes that may facilitate pluton emplacement, but whether it represents a volumetrically significant process remains 
controversial (Marsh, 1982; Yoshinobu et al., 2003; Glazner and Bartley, 2006). Stoping by plutons of the North Cascades crystalline core has been described in multiple Cretaceous plutons (Miller et al., 2009a).

Xenoliths were observed in two, 100-200-m-wide, 1-2-km-long zones along parts of the southern and southwestern Golden Horn batholith contact, in the two-feldspar biotite granite and the alkaline granite, where the batholith intruded the Midnight Peak Formation (Figs. 2 and 18). These xenoliths had sharp boundaries and range in width from centimeters to several meters. Some meter-sized xenoliths were fractured into several smaller blocks. The sharp boundaries of the xenoliths may be attributed to the melt cooling quickly against relatively cool host rock, fast injection rates, or both. Stoping clearly contributed to emplacement; however, its restriction to the southern and southwestern contacts makes it unclear how significant of a material transfer process it was during the intrusion of the batholith.

\section{Uplift and Floor Subsidence}

Roof uplift has been documented for a number of shallowly emplaced plutons and laccoliths (e.g., Corry, 1988; Paterson et al., 1996; Benn et al., 1998; Acocella, 2000; Yoshinobu et al., 2003). It has been estimated that the Golden Horn batholith was emplaced at a depth of $\sim 8 \mathrm{~km}$ based on compositions of Golden Horn granites, which plot near the water-saturated eutectic in the quartz-albite-orthoclase system (Eddy et al., 2016a). This evidence for shallow emplacement indicates that roof uplift is a potentially viable mechanism. No pluton roof was observed in the study areas. Features that could support uplift are the tightly folded and overturned beds of the Cretaceous sedimentary 
rocks of the Midnight Peak, and Virginian Ridge Formations to the east of the batholith (McGroder, 1990) (Fig. 10). However, these folds and overturned beds extend up to 20 $\mathrm{km}$ from the contact; attributing them to roof uplift is questionable.

There are also several thrust faults, folds, and oblique dextral faults along the southeastern margin of the batholith, but these structures are Cretaceous in age, predating the batholith (McGroder et al., 1990). Other possible evidence for piston-like uplift would be steep dip-slip faults along the pluton sides (Paterson et al., 1996), but such structures have not been recognized.

Floor subsidence is a ductile material transfer process associated with deeper-crustal intrusions (e.g., Buddington, 1959; Cruden, 1998). Floor subsidence is most commonly identified by ductile flow along pluton walls or sagging of the host rock (Cruden, 1998). A ductile structural aureole was not observed in the host rocks next to the pluton walls, nor was downward sagging of the host rock. Nowhere in the study areas is the pluton floor exposed; thus, although floor subsidence cannot be ruled out, there is no evidence that it contributed to emplacement.

\section{Faulting}

Another material transfer process for accommodating magma is through a zone of lateral extension by dilational faulting (e.g., Hutton, 1988; Lacroix et al., 1998), although it has been argued that the extension rates are too slow to allow a magma chamber to form (Hansen and Glazner, 1995). Many of the plutons in the Cascade core are not associated spatially with map-scale faults or shear zones (Miller et al., 2009a). However, the Golden Horn batholith, Ruby Creek heterogeneous plutonic belt, Black Peak 
batholith, and Oval Peak pluton lay within the Ross Lake fault zone, a 200-km-long, 15km-wide system of faults and fault zones that make up the eastern boundary of the Cascade core (Misch, 1966; Miller and Bowring, 1990). The Ross Lake fault zone experienced a diachronous history during the Late Cretaceous to Eocene dominated by dextral strike-slip, but with components of reverse slip at $~ 65$ Ma followed by normal slip as young as $45 \mathrm{Ma}$ (Miller and Bowring, 1990; Haugerud et al., 1991). Motion along this fault zone in the region of the Golden Horn batholith reportedly ceased by 49 Ma, before intrusion of the batholith (Miller and Bowring, 1990).

The Golden Horn batholith is cut along its southwest contact by several E-W-striking, sinistral strike-slip faults (Fig. 17). These faults postdate emplacement, as they offset the batholith, and likely did not contribute to emplacement. Two major NW-striking, dextral strike-slip faults of the Ross Lake fault zone occur to the north and south of the Golden Horn batholith (Fig. 17). To the north is the Hozameen fault and to the southeast along strike is the North Creek fault (Fig. 17). These faults are cut by the batholith and thus were not active during emplacement. They may have indirectly affected magma ascent by providing an anisotropic pathway.

In summary, no single emplacement mechanism can account for the volumes of material transport needed for the Golden Horn batholith. The lack of a structural aureole around the pluton, as well as the presence of xenolith-rich zones imply that ductile flow was likely not a material transfer process. Stoping is observed along the southwestern and southern boundaries of the batholith, but not in significant enough volumes to be the only emplacement mechanism. Roof uplift is a possible mechanism given the shallow 
emplacement $(\sim 8 \mathrm{~km})$. Faulting did not act as a material transfer process during emplacement, but may have provided an anisotropic pathway for magma.

\section{Tilting of the Golden Horn Batholith}

Stull (1987) first proposed that the Golden Horn batholith is tilted so that the northwest end has been brought up. He came to this conclusion based on his observations that Golden Horn rocks to the northwest are more mafic, contain enclaves, and are more hybridized than the alkaline granites to the southeast. Stull (1987) further postulated that the more mafic rocks were later-stage injections that underplated the granites. Hopson and Mattinson (1994) suggested that the Ruby Creek heterogeneous

plutonic belt, which bounds the Golden Horn batholith on the NW, represents the roots of the batholith, compatible with tilting.

The internal contact between the one feldspar-biotite granite and the alkaline granite near Washington Pass is gently dipping $\left(<20^{\circ}\right)$ to the SE, but steepens to $\sim 50^{\circ}$ farther north near Cutthroat Pass. Near Blue Lake, west of Washington Pass, the contact dips $\sim 32^{\circ}$ to the SE (Fig. 10). The steepening of the contact to the north may result from drag as it approaches a map-scale normal fault (Fig. 17). This fault forms the northwest and northern contact of the alkaline and one feldspar-biotite granites, and juxtaposes them with the two feldspar-biotite granite. This fault brought the structurally higher one feldspar-biotite granite and alkaline granite down against the one feldspar-biotite granite. Eddy et al. (2016a) also noted that the internal units of the Golden Horn batholith are roughly sub-horizontal and dip to the southeast. They also interpreted the alkaline granite 
as the structurally highest unit, and the more mafic granodiorites to the northwest as the structurally lowest unit.

\section{Magmatic Structures}

In the study area, magmatic structures such as foliation, lineation, aplite dikes, minor schlieren, and enclaves were observed. However, ladder dikes, pipes, troughs, and tubes were not observed; these structures ideally require injection into a permeable crystal mush (Weinberg, 2001; Paterson, 2009). Their absence may reflect the very rapid emplacement rate of $0.0125 \mathrm{~km}^{3} / \mathrm{yr}$ for the Golden Horn batholith (Eddy et al., 2016a). Overlapping zircon dates from widely spaced samples within the two feldspar-biotite granite indicate that melt was simultaneously present throughout that unit (Eddy et al., 2016a).

Schlieren were observed locally in the granodiorite in the northwestern part of the batholith and in the one- and two feldspar-biotite granites in the southeastern part of the batholith. The schlieren ranged from meter-long bands to slight wisps of mafic minerals only a few centimeters long. They are generally parallel to the regional foliation and accompanied by enclaves. The interpreted leading edges of the enclaves are sharp, whereas the tailing edges are more embayed, wavy, and have wispy tails. This pattern may result from slight quenching along the inferred leading edge, and more interaction with the resident magma along the back end. Schlieren typically form through mixing and magma flow against internal or external contact (e.g., Weinberg, 2001), but were not observed in greater abundance near internal contacts or host rock contacts. I interpret that disaggregation of enclaves is likely the only source of schlieren in the Golden Horn 
batholith, No enclave swarms were observed in the mapped areas or by previous workers. This may be evidence that there was only a minor change to the magma source during

construction. Also, if a large magma chamber formed rapidly, a crystal mush would still form, but with no late injections of younger magma, schlieren would not be widespread, and tubes, ladder dikes, and pipes would not form.

\section{Development of Foliation Patterns}

The Golden Horn batholith in the study area contains two dominant fabrics. One is a weak NE-striking, steeply dipping foliation defined mostly by biotite and to a lesser extent hornblende, and is restricted to the center of the intrusion. This foliation is interpreted as magmatic, recording early-stage, internal processes such as convection and new magma injection (e.g., Tobisch et al., 1997; Paterson et al., 1998).

The second foliation orientation is a stronger, NW-striking, and typically steeply $\left(>60^{\circ}\right) \mathrm{SW}$-dipping fabric that is consistent across the entire $\sim 48 \mathrm{~km}$ length of the batholith. Foliation is sub-parallel with parts of the southern contact ( $\mathrm{S}$ and $\mathrm{W}$ of Washington Pass) (Fig. 10). This foliation is also discordant with the NW contact along Highway 20, and the SE contact near the North Creek trail (Fig. 2).

The NW-striking foliation has the least variation in strike in the northwestern part of the batholith. This relationship supports the inference that this part of the batholith is structurally deeper as it may have taken relatively longer to cool, allowing greater time for more of the crystals in the mush to record regional strain.

Plutons constructed by sub-horizontal sheets, such as the Golden Horn batholith, may have sub-horizontal foliations resulting from compaction due to repeated injections 
(Wiebe and Collins, 1998). The steep foliations in the Golden Horn batholith are not compatible with this interpretation and support the hypothesis that the foliations reflect internal flow, not compaction, and regional strain. The NW-striking foliation likely reflects the NE-SW shortening component during ridge-trench interaction off the coast at 50-48 Ma (e.g., Engebretson et al., 1985; Madsen et al., 2006).

\section{Golden Horn Dikes}

Dikes typically help to show regional strain fields in the crust during emplacement. In general, dikes form parallel to the greatest compressional stress and perpendicular to the least compressional stress (Anderson, 1951; Gudmundsson, 1984). Multiple dikes of Golden Horn and more mafic composition intrude the host rock in various locations next to the batholith, notably along the Methow River and in the Silent Lakes area (Fig 19). These dikes have two main strikes: NE and $\sim \mathrm{E}-\mathrm{W}$.

Dikes intrude the Harts Pass Formation along the Methow River (Fig 15). These mafic dikes strike approximately NE, dip steeply, range from $1 \mathrm{~m}$ to roughly $100 \mathrm{~m}$ across, and extend for up to $3 \mathrm{~km}$ in map view. Farther northeast, dikes related to the Eocene Monument Peak pluton, Golden horn batholith, or both, were mapped by Tabor et al. (1968) (see Structure, Fig. 15). The majority of these dikes also strike NE. The orientations of these dikes NE of the Golden Horn batholith are similar to many other dikes measured in the North Cascades core and Swauk Formation (Fig. 19), and likely record regional Eocene NW-SE extension.

Within a kilometer of the southwestern batholith contact, Golden Horn dikes intrude metasedimentary rocks of the Methow basin and the Black Peak batholith (see Structure, 
Fig. 14). These dikes are rapikivi porphyry, generally strike WNW, dip greater than $65^{\circ}$ north and south, are up to $30 \mathrm{~m}$ in width, and can be traced for up to $3 \mathrm{~km}$ on Google Earth. Dikes south of the batholith intrude the Black Peak batholith along Highway 20 near Blue Lake, and near North Creek Trail (Fig. 14). These mafic dikes have E-W $\left(\sim 075^{\circ}-115^{\circ}\right)$ strikes, both north and south dips, and have varying thicknesses.

Similar dike orientations have been observed $\sim 25 \mathrm{~km}$ to the south in the central part of the Skagit Gneiss Complex (Miller et al., 2016). I interpret that the WNW-striking Golden Horn dikes followed an anisotropic pathway parallel to the E-W-trending strikeslip faults that cut the batholith. 


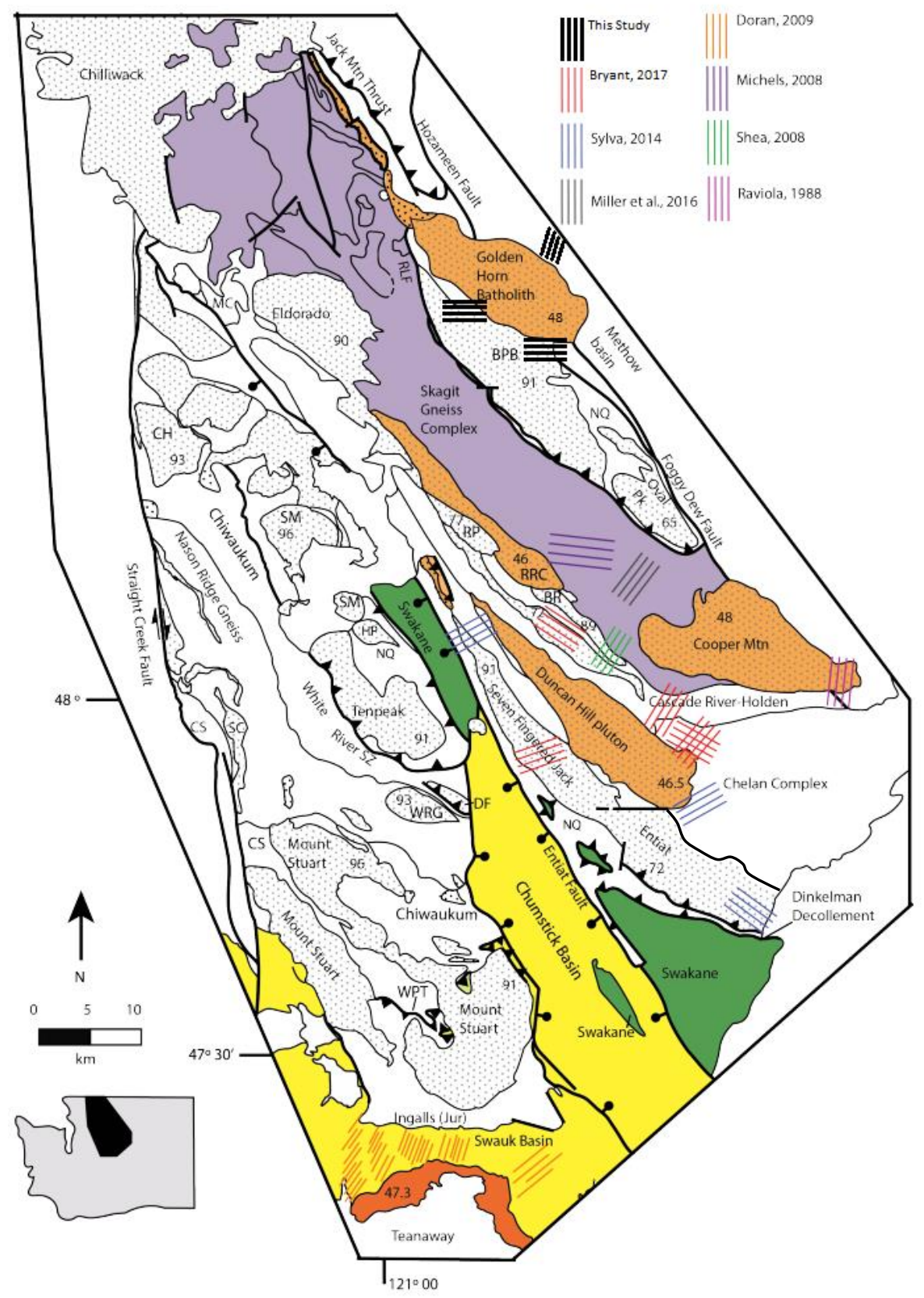

Figure 19. Simplified map of regional dike orientations in the North Cascades. Black lines next to the Golden Horn batholith represent dike trends measured during this study, and colored lines represent dike trends measured by others. BPB (Black Peak batholith); BR (Bearcat Ridge orthogneiss); CH(Chaval pluton); CS (Chiwaukum Schist); DF (Dirtyface pluton); MC (Marble Creek pluton); NQ (Napeequa complex); RLF (Ross Lake fault); RP (Riddle Peaks pluton); RRC (Railroad Creek pluton); SC (Sloan Creek pluton); SM (Sulphur Mountain pluton); WPT (Windy Pass thrust); WRG (Wenatchee Ridge Gneiss). Modified from Miller et al. (2009b). 


\section{CONCLUSIONS}

Through field mapping, structural analysis, and examination of thin sections, the following conclusions have been drawn about the emplacement of the Golden Horn batholith and the regional strain during emplacement.

1. The Golden Horn batholith was constructed very quickly $(739 \pm 34$ k.y) in the shallow crust, and no single emplacement mechanism can account for the volumes of material transport needed for the Golden Horn batholith. The lack of a structural aureole around the pluton, as well as the presence of xenolith-rich zones, imply that ductile flow was likely not a material transfer process. There is evidence of stoping along the southwestern and southern boundaries of the batholith, but not in significant enough volumes to be the only emplacement mechanism. Roof uplift is another possible emplacement mechanism, though no evidence for it was found. Faults may have provided an anisotropic pathway for magma.

2. The pluton contains two magmatic foliation patterns, and one weak lineation. One foliation is weak, strikes northeast, dips steeply, and is confined to the central part of the batholith. This foliation probably records early magmatic processes. The other foliation is stronger, strikes northwest, dips steeply, and probably records a component of NE-SW shortening in an overall transtentional regime. The lineation is weak and predominantly trends northwest across the pluton, plunges shallowly $\left(<30^{\circ}\right)$, and probably records regional NW-SE extension.

3. Dikes interpreted to be related to the Golden Horn batholith intrude the host rocks of the intrusion. The dikes south and west of the batholith strike approximately 
E-W, and the dikes NE of the batholith strike NE. Some of the E-W-striking dikes may be guided by a zone of E-W-trending sinistral strike-slip faults. The NEstriking dikes support the interpretation of regional NW-SE extension during their emplacement. 


\section{REFERENCES CITED}

Acocella, V., 2000, Space accommodation by roof lifting during pluton emplacement at Amiata (Italy): Terra Nova, v. 12, p. 149-155.

Adams, J.B., 1961, Petrology and structure of the Stehekin-Twisp Pass area, North Cascades, Washington [Ph.D. thesis]: Seattle, University of Washington, $171 \mathrm{p}$.

Adams, J.B., 1964, Origin of the Black Peak Quartz Diorite, Northern Cascades, Washington: American Journal of Science, v. 262, p. 290-306.

Anderson, E.M., 1951, The dynamics of faulting and dyke formation with applications to Britain, $2^{\text {nd }}$ edition: Hafner Publishing Company, 206 p.

Armstrong, R.L., 1988, Mesozoic and early Cenozoic magmatic evolution of the Canadian Cordillera: Geological Society of America Special Paper 218, p. 55-91.

Benn, K., Odonne, F., and de Saint-Blanquat, M., 1998, Pluton emplacement during transpression in brittle crust: new views from analog experiments: Geology, v. 26, p. 1079-1082.

Benn, K., Roest, W.R., Rochette, P., Evans, N.G., and Pignotta, G.S., 1999, Geophysical and structural signatures of syntectonic batholith construction: the South Mountain Batholith, Meguma Terrane, Nova Scotia: Geophysical Journal International, v. 136, p. 144-158.

Boggs, R.C., 1984, Mineralogy and geochemistry of the Golden Horn batholith, Northern Cascades, Washington [Ph.D. thesis]: Santa Barbara, University of California, 187 p.

Brown, E.H., and McClelland, W.C., 2000, Pluton emplacement by sheeting and vertical ballooning in part of the southeast Coast Plutonic Complex, British Columbia: Geological Society of America Bulletin, v. 112, p. 708-719, doi:10.1130/00167606(2000)1122.3.CO;2.

Bryant, K.I., 2017, Structural analysis of Eocene dike swarms in and near the Duncan Hill pluton, North Cascades, Washington [M.S. thesis]: San Jose, California, San Jose State University, 71 p.

Buddington, A.F., 1959, Granite emplacement with special reference to North America: Geological Society of America Bulletin, v. 70, p. 671-747. 
Clarke, D.B., Henry, A.S., and White, M.A., 1998, Exploding xenoliths and the absence of 'elephants' graveyards' in granite batholiths: Journal of Structural Geology, v. 20, p. $1325-1343$.

Clemens, J.D., and Mawer, C.K., 1992, Granitic magma transport by fracture propagation: Tectonophysics, v. 204, p. 339-360.

Corry, C.E., 1988, Laccoliths: mechanics of emplacement and growth: Geological Society of America, v. 220, 110 p.

Cowan, D.S., 2003, Revisiting the Baranof-Leech River hypothesis for early Tertiary coastwise transport of the Chugach-Prince William terrane: Earth and Planetary Science Letters, v. 213, p. 463-475.

Cruden, A.R., 1998, On the emplacement of tabular granites: Journal of the Geological Society, v. 155, p. 853-862.

Doran, B., 2009, Structure of the Swauk Formation and Teanaway dike swarm, Washington Cascades [M.S. thesis]: San Jose, California, San Jose State University, $97 \mathrm{p}$.

Dragovich, J.D., Norman, D.K., Haugerud, R.A., and Miller, R.B., 1997, Geologic map of the Gilbert 7.5' quadrangle, Chelan and Okanogan Counties, Washington:

Washington Division of Geology and Earth Resources Geologic Map GM-46, scale $1: 24,000$.

Dragovich, J.D., Logan, R.L., Schasse, H.W., Lingley, W.S. Jr, Norman, D.K., Gerstel, W.J., Lapen, T.J., and Schuster, J.E., 2002, Geologic map of Washington-Northwest quadrant: Washington Division of Geology and Earth Resources, Geologic Map GM50, 1 sheet, scale 1:250,000.

Eddy, M.P., Bowring, S.A., Miller, R.B., and Tepper, J.H., 2016a, Rapid assembly and crystallization of a fossil large-volume silicic magma chamber: Geology, v. 44, p. 331-334.

Eddy, M.P., Bowring, S.A., Umhoefer, P.J., Miller, R.B., McLean, N.M., and Donaghy, E.E., 2016b, High-resolution temporal and stratigraphic record of Siletzia's accretion and triple junction migration from nonmarine sedimentary basins in central and western Washington: Geological Society of America Bulletin, v. 128, p. 425-441, doi: $10.1130 / \mathrm{B} 31335.1$. 
Engebretson, D.C., Cox, A., and Gordon, R.G., 1985, Relative motions between oceanic and continental plates in the Pacific Basin: Geological Society of America Special Paper 209, 59 p.

Engels, J.C., Tabor, R.W., Miller, F.K., and Obradovich, J.D., 1976, Summary of K-Ar, $\mathrm{Rb}-\mathrm{Sr}, \mathrm{U}-\mathrm{Pb}$, and fission track ages of rocks from Washington State prior to 1975 (exclusive of Columbia Plateau Basalts): U.S. Geological Survey Miscellaneous Field Studies Map MF-710.

Gehrels, G., Rusmore, M., Woodsworth, G., Crawford, M., Andronicos, C., Hollister, L., Patchett, J., Ducea, M., Butler, R., Klepeis, K., and Davidson, C., 2009, U-Th-Pb geochronology of the Coast Mountains batholith in north-coastal British Columbia: Constraints on age and tectonic evolution: Geological Society of America Bulletin, v. 121, p. 1341-1361.

Glazner, A.F., and Bartley, J.M., 2006, Is stoping a volumetrically significant pluton emplacement process?: Geological Society of America Bulletin, v. 118, p. 11851195.

Gordon, S.M., Whitney, D.L., Miller, R.B., McLean, N., and Seaton, N.C.A., 2010, Metamorphism and deformation at different structural levels in a strike-slip fault zone, Ross Lake fault, North Cascades, USA: Journal of Metamorphic Geology, v. 28, p. 117-136, doi: 10.1111j.1525-1314.2009.00860.x.

Groome, W.G. and Thorkelson, D.J., 2009, The three-dimensional thermo-mechanical signature of ridge subduction and slab window migration: Tectonophysics, v. 464, p.70-83.

Gudmundsson, A., 1984, Formation of dykes, feeder-dykes, and the intrusion of dykes from magma chambers: Bulletin Volcanologique, v. 47, p. 537-550.

Haeussler, P.J., Bradley, D.C., Wells, R.E., and Miller, M.L., 2003, Life and death of the Resurrection plate: Evidence for its existence and subduction in the northeastern Pacific in Paleocene-Eocene time: Geological Society of America Bulletin, v. 115, p. 867-880.

Hanson, R.B., and Glazner, A.F., 1995, Thermal requirements for extensional emplacement of granitoids: Geology, v. 23, p. 213-216.

Haugerud, R.A., 1985, Geology of the Hozameen Group and the Ross Lake shear zone, Maselpanik area, North Cascades, southwest British Columbia [Ph.D. thesis]: Seattle, University of Washington, 263 p. 
Haugerud, R.A., and Tabor, R.W., 2009, Geologic map of the North Cascade Range, Washington: U.S. Geological Survey, Scientific Investigations Map 2940, 2 sheets, scale 1:200,000; 2 pamphlets, 29 p. and 23 p.

Haugerud, R.A., Van der Heyden, P., Tabor, R.W., Stacey, J.S., and Zartman, R.E., 1991, Late Cretaceous and early Tertiary plutonism and deformation in the Skagit gneiss complex, North Cascade Range, Washington and British Columbia: Geological Society of America Bulletin, v. 103, p. 1297-1307.

Hopson, C.A., and Mattinson, J.M., 1994, Chelan Migmatite Complex: Field evidence for mafic magmatism, crustal anatexis, mixing and protodiapiric emplacement, in Swanson, D.A., and Haugerud, R.A., eds., Geologic field trips in the Pacific Northwest: Geological Society of America Annual Meeting, Seattle, University of Washington Publication, p. 2K1-2K21.

Hutton, D.H., 1988, Granite emplacement mechanisms and tectonic controls: inferences from deformation studies: Earth and Environmental Science Transactions of the Royal Society of Edinburgh, v. 79, p. 245-255.

Hutton, D.H., 1992, Granite sheeted complexes: evidence for the dyking ascent mechanism: Earth and Environmental Science Transactions of the Royal Society of Edinburgh, v. 83, p. 377-382.

Ingram, G.M., and Hutton, D.H., 1994, The Great Tonalite Sill: Emplacement into a contractional shear zone and implications for Late Cretaceous to early Eocene tectonics in southeastern Alaska and British Columbia: Geological Society of America Bulletin, v. 106, p. 715-728.

Johnston, S.T., and Thorkelson, D.J., 1997, Cocos-Nazca slab window beneath Central America: Earth and Planetary Science Letters, v. 146, p. 465-474.

Kamb, W.B., 1959, Ice petrofabric observations from Blue Glacier, Washington, in relation to theory and experiment: Journal of Geophysical Research, v. 64, p. 18911909, doi: 10.1029/JZ064i011p01891.

Lacroix, S., Sawyer, E.W., and Chown, E.H., 1998, Pluton emplacement within an extensional transfer zone during dextral strike-slip faulting: an example from the late Archaean Abitibi Greenstone Belt: Journal of Structural Geology, v. 20, p. 43-59.

Madsen, J.K., Thorkelson, D.J., Friedman, R.M., and Marshall, D.D., 2006, Cenozoic to Recent plate configurations in the Pacific Basin: Ridge subduction and slab window magmatism in western North America: Geosphere, v. 2, p. 11-34. 
Marsh, B.D., 1982, On the mechanics of igneous diapirism, stoping, and zone melting: American Journal of Science, v. 282, p. 808-855.

Matzel, J.E., Bowring, S.A., and Miller, R.B., 2004, Protolith age of the Swakane Gneiss, North Cascades, Washington: Evidence of rapid underthrusting of sediments beneath an arc: Tectonics, v. 23, p. TC6009, doi: 10.1029/2003TC001577.

McNulty, B.A., Tong, W., and Tobisch, O.T., 1996, Assembly of a dike-fed magma chamber: The Jackass Lakes pluton, central Sierra Nevada, California: Geological Society of America Bulletin, v. 108, p. 926-940.

McGroder, M. F., 1988, Structural evolution of the eastern Cascades foldbelt: Implications for late Mesozoic accretionary tectonics in the Pacific Northwest [Ph.D. thesis]: Seattle, University of Washington, $140 \mathrm{p}$.

McGroder, M. F., 1989, Structural geometry and kinematic evolution of the eastern Cascades foldbelt, Washington and British Columbia: Canadian Journal of Earth Sciences, v. 26, p. 1586-1602.

McGroder, M. F., Garver, J.I., and Malloy, V.S., 1990, Bedrock geologic map, biostratigraphy, and structure sections of the Methow Basin, Washington and British Columbia: Washington Division of Geology and Earth Resources Open File Report 90-19, 32 p., 3 plates.

Michels, Z.D., 2008, Structure of the Central Skagit Gneiss Complex, North Cascades, Washington [M.S. thesis]: San Jose, California, San Jose State University, 67 p.

Miller, R.B., 1987, Geology of the Twisp River-Chelan Divide region, North Cascades, Washington: Washington Division of Geology and Earth Resources Open-File Report 87-17, $12 \mathrm{p}$.

Miller, R.B., 1994, A midcrustal contractional stepover zone in a major strike-slip system, North Cascades, Washington: Journal of Structural Geology, v. 16, p. 47-60.

Miller, R.B., and Bowring, S.A., 1990, Structure and chronology of the Oval Peak batholith and adjacent rocks: Implications for the Ross Lake fault zone, North Cascades, Washington: Geological Society of America Bulletin, v. 102, p. 13611377.

Miller, R.B., and Paterson, S.R., 1994, Transition from magmatic to high-temperature solid-state deformation, Mount Stuart batholith, Washington: Journal of Structural Geology, v. 16, p. 853-865. 
Miller, R.B., and Paterson, S.R., 1999, In defense of magmatic diapirs: Journal of Structural Geology, v. 21, p. 1161-1173.

Miller, R.B., and Paterson, S.R., 2001, Construction of mid-crustal sheeted plutons: Examples from the North Cascades, Washington: Geological Society of America Bulletin, v. 113, p. 1423-1442.

Miller, R.B., Bowring, S.A., and Hoppe, W.J., 1989, Paleocene plutonism and its tectonic implications, North Cascades, Washington: Geology, v. 17, p. 846-849, doi: 10.1130 /0091-7613(1989)017<0846:PPAITI> 2.3.CO;2.

Miller, R.B., Haugerud, R.H., Murphy, F., and Nicholson, L.S., 1994, Tectonostratigraphic framework of the northeastern Cascades: Washington Division of Geology and Earth Resources Bulletin, v. 80, p. 73-92.

Miller, R.B., Paterson, S.R., and Matzel, J.P., 2009a, Plutonism at different crustal levels: Insights from the $\sim 5-40 \mathrm{~km}$ (paleodepth) North Cascades crustal section, Washington, in Miller, R.B., and Snoke, A.W, eds., Crustal cross sections from the western North American Cordillera and elsewhere: Implications for tectonic and petrologic processes: Geological Society of America Special Paper 456, p. 125-149, doi: 10.1130/2009.2456(05).

Miller, R.B., Gordon, S.M., Bowring, S.A., Doran, B.A., McLean, N.M., Michels, Z.D., Shea, E.K., Whitney, D.L., Wintzer, N.E., and Mendoza, M.K., 2009b, Linking deep and shallow crustal processes in an exhumed continental arc, North Cascades, Washington, in O'Connor, J.E., Dorsey, R.J., and Maddin, I.P., eds., Volcanoes to vineyards: Geologic field trips through the dynamic landscape of the Pacific Northwest: Geological Society of America Field Guide 15, p. 373-406.

Miller, R.B., Gordon, S.M., Bowring, S., Doran, B., McLean, N., Michels, Z., Shea, E., and Whitney, D.L., 2016, Linking deep and shallow crustal processes during regional transtension in an exhumed continental arc, North Cascades, northwestern Cordillera: Geosphere, v. 12, p. 900-924, doi: 10.1130/GES01262.1.

Marsh, B.D., 1982, On the mechanics of diapirism, stoping and zone melting: American Journal of Science, v. 282, p. 808-855.

Misch, P., 1966, Tectonic evolution of the Northern Cascades of Washington State: a west-Cordilleran case history: Canadian Institute of Mining and Metallurgy, Special Volume 8, p. 101-148. 
Misch, P., 1977a, Bedrock geology of the North Cascades, in Brown, E.H., and Ellis, R.C., eds., Geological excursions in the Pacific Northwest: Bellingham, Western Washington University, p. 1-62.

Monger, J.W.H., 1986, Geology between Harrison Lake and Fraser River, Hope Map area, southwestern British Columbia, in Current research, Part B: Geological Survey of Canada Paper 86-1B, p. 699-706.

Monger, J.W.H., Van der Heyden, P., Journeay, J.M., Evenchick, C.A., and Mahoney, J.B., 1994, Jurassic-Cretaceous basins along the Canadian Coast Belt: Their bearing on pre-mid-Cretaceous sinistral displacements: Geology, v. 22, p. 175-178.

Morgan, S.S., Law, R.D., and Nyman, M.W., 1998, Laccolith-like emplacement model for the Papoose Flat pluton based on porphyroblast-matrix analysis: Geological Society of America Bulletin, v. 110, p. 96-110, doi: 10.1130/00167606(1998) 1102.3.CO;2.

Parrish, R.R., Carr, S.D., and Parkinson, D.L., 1988, Eocene extensional tectonics and geochronology of the southern Omineca Belt, British Columbia and Washington: Tectonics, v. 7, p. 181-212.

Paterson, S.R., 2009, Magmatic tubes, pipes, troughs, diapirs, and plumes: Late-stage convective instabilities resulting in compositional diversity and permeable networks in crystal-rich magmas of the Tuolumne batholith, Sierra Nevada, California: Geosphere, v. 5, p. 496-527.

Paterson, S.R., and Fowler, T.K., Jr., 1993, Re-examining pluton emplacement processes: Journal of Structural Geology, v. 15, p. 191-206.

Paterson, S.R., and Tobisch, O.T., 1992, Rates of processes in magmatic arcs: implications for the timing and nature of pluton emplacement and wall rock deformation: Journal of Structural Geology, v. 14, p. 291-300.

Paterson, S.R., and Miller, R.B., 1998, Mid-crustal magmatic sheets in the Cascades Mountains, Washington: implications for magma ascent: Journal of Structural Geology, v. 20, p. 1345-1363.

Paterson, S.R., Fowler, T.K., Jr., and Miller, R.B., 1996, Pluton emplacement in arcs: a crustal-scale exchange process: Geological Society of America Special Papers, v. 315 , p. 115-123. 
Paterson, S.R., Fowler, T.K., Jr., Schmidt, K.L., Yoshinobu, A.S., Yuan, E.S., and Miller, R.B., 1998, Interpreting magmatic fabrics in plutons: Lithos, v. 44, p. 53-82, doi: 10.1016/S0024-4937(98)00022-X.

Petford, N., 1996, Dykes or diapirs?: Transactions of the Royal Society of Edinburgh: Earth Sciences, v. 87, p. 105-114.

Petford, N., 2003, Rheology of granitic magmas during ascent and emplacement: Annual Review of Earth and Planetary Sciences, v. 31, p. 399-427.

Petford, N., Cruden, A.R., McCaffrey, K.J.W., and Vigneresse, J.-L., 2000, Granite magma formation, transport and emplacement in the Earth's crust: Nature, v. 408, p. $669-673$.

Raviola, F.P., 1988, Metamorphism, plutonism and deformation in the Pateros-Alta Lake region, North-Central Washington [M.S. thesis]: San Jose, California, San Jose State University, $181 \mathrm{p}$.

Shea, E.K.M., 2008, Structure of the southern Skagit Gneiss Complex, North Cascades, Washington [M.S. thesis]: San Jose, California, San Jose State University, 90 p.

Shea, E.K., Miller, J.S., Miller, R.B., Bowring, S.A., and Sullivan, K.M., 2016, Growth and maturation of a mid-to shallow-crustal intrusive complex, North Cascades, Washington: Geosphere, v. 12, p. 1489-1516, doi: 10.1130/GES01290.1.

Sisson, V.B., Pavlis, T.L., Roeske, S.M., and Thorkelson, D.J., 2003, Introduction: An overview of ridge-trench interaction in modern settings, in Sisson, V. B., Roeske, S.M., and Pavlis, T.L., eds., Geology of a transpressional orogen developed during ridge-trench interaction along the North Pacific margin: Geological Society of America Special Paper 371, p. 1-18.

Stull, R.J., 1969, The geochemistry of the southeastern portion of the Golden Horn batholith, Northern Cascades, Washington [Ph.D. thesis]: Seattle, University of Washington, $127 \mathrm{p}$.

Stull, R.J., Misch, P., and Davis, T.E., 1987, Progressive partial melting and magma mixing in the anorogenic Golden Horn batholith, Washington: Unpublished manuscript, $47 \mathrm{p}$.

Sylva, N.L., 2014, Structure of Eocene dikes south of the Duncan Hill pluton, North Cascades, Washington: Implications for regional strain during postulated ridge subduction [B.S. Thesis]: San Jose, California, San Jose State University, 25 p. 
Tabor, R.W., Engels, J.C., and Staatz, M.H., 1968, Quartz diorite-quartz monzonite and granite plutons of the Pasayten River area, Washington - Petrology, age, and emplacement: U.S. Geological Survey Professional Paper 600-C, p. C-45-52.

Tabor, R.W., Frizzell, V.A., Jr., Vance, J.A., and Naeser, C.W., 1984, Ages and stratigraphy of lower and middle Tertiary sedimentary and volcanic rocks of the central Cascades, Washington: Application to the tectonic history of the Straight Creek fault: Geological Society of America Bulletin, v. 95, p. 26-44.

Tabor, R.W., Frizzell, V.A., Jr., Whetten, J.T., Waitt, R.B., Swanson, D.A., Byerly, G.R., Booth, D.B., Hetherington, M.J., and Zartman, R.E., 1987, Geologic map of the Chelan 30-minute by 60-minute Quadrangle, Washington: U.S. Geological Survey Map I-1661, scale 1:100,000.

Tabor, R.W., Haugerud, R.A., and Miller, R.B., 1989, Overview of the geology of the North Cascades: International Geological Congress Trip T307: American Geophysical Union, p. 1-62.

Tabor, R.W., Haugerud, R.A., Hildreth, W., and Brown, E.H., 2003, Geologic map of the Mount Baker 30- x 60-minute quadrangle, Washington: U.S. Geological Survey Geologic Investigations Series Map I-2660, scale 1:100,000, 73 p.

Thorkelson, D.J., and Taylor, R.P., 1989, Cordilleran slab windows: Geology, v. 17, p. 833-836.

Tobisch, O.T., McNulty, B.A., and Vernon, R.H., 1997, Microgranitoid enclave swarms in granitic plutons, central Sierra Nevada, California: Lithos, v. 40, p. 321-339.

Yoshinobu, A.S., Fowler, T.K. Jr., Paterson, S.R., Llambias, E., Tickyj, H., and Sato, A.M., 2003, A view from the roof: magmatic stoping in the shallow crust, Chita pluton, Argentina: Journal of Structural Geology, v. 25, p. 1037-1048.

Weinberg, R.F., 1994, Re-examining pluton emplacement processes: discussion: Journal of Structural Geology, v. 16, p. 743-760.

Weinberg, R.F., 1999, Mesoscale pervasive felsic magma migration: Alternatives to dyking: Lithos, v. 46, p. 393-410.

Weinberg, R.F., Sial, A.N., and Pessoa, R.R., 2001, Magma flow within the Tavares pluton, northeastern Brazil: Compositional and thermal convection: Geological Society of America Bulletin, v. 113, p. 508-520. 
Wernicke, B., and Getty, S.R., 1997, Intracrustal subduction and gravity currents in the deep crust: Sm-Nd, Ar-Ar, and thermobarometric constraints from the Skagit Gneiss Complex, Washington: Geological Society of America Bulletin, v. 109, p. 1149-1166.

Wiebe, R.A., and Collins, W.J., 1998, Depositional features and stratigraphic sections in granitic plutons; implications for the emplacement and crystallization of granitic magma: Journal of Structural Geology, v. 20, p. 1273-1289. 